\title{
Advanced Selection Materials in Solar Cell Efficiency and their Properties- A Comprehensive Review
}

\author{
Ibrahim M. Alarifi ${ }^{1,2, *}$
}

1 Department of Mechanical and Industrial Engineering, College of Engineering, Majmaah University, AlMajmaah, Riyadh, Saudi Arabia; i.alarifi@mu.edu.sa

2 Engineering and Applied Science Research Center, Majmaah University, Al-Majmaah, Riyadh, Saudi Arabia; i.alarifi@mu.edu.sa

* Correspondence: i.alarifi@mu.edu.sa; Tel.: (+966502222828; Ibrahim M. Alarifi, IA)

\begin{abstract}
Solar cell layers technology has achieved global standing in the solar cell layers deposition process, and it covers the innovative methods and techniques in significant applications. Recent solar cell layers technology has an advanced interest in a refined approach to enhance performance and highlights the importance of recent proficient procedures for manufacturing. For example, the application is used to search for novel materials for solar cells' layers to clarify the current energy crisis. The technological process and various types of solar cells depend on climate change. Among them, layers of solar cells and silicon wafer solar cells are very encouraging. Solar cell layers technology has led to solar cells being a more reasonable active option in design and production. The productivities facilitated by new solar cells still need to be enhanced for the various processes involved in the additional enhancement from Copper Indium Gallium Selenide (CIGS) microfilms to solar cell crystal structure dye-sensitized solar cells. The hydrophobic coating works as an anti-dust coating, enhancing efficiency and decreasing the cost of cleaning solar cells. In Saudi Arabia Majmaah City, most solar projects are in dry regions, where the dusty weather reduces solar cell efficiency. Therefore, combining these two properties and applying an anti-reflective and superhydrophobic coating will increase solar cell efficiency by $20 \%$. Solar cells' crystal structure results are substituted with layers or new materials to balance environmental impact and toxic nature.
\end{abstract}

Keywords: Copper indium gallium selenide layers; Solar cell efficiency; Self-cleaning; Superhydrophobic coatings; Vapour deposition technique.

\section{Introduction}

The quest for a viable alternative to hydrocarbons has drawn an excessive deal of consideration during the current energy crisis, and alternative platforms include solar, wind, and nuclear energy. Furthermore, an attractive form of limitless alternative energy is provided by solar cells. Solar cell placement can offer a thermal energy source and electricity as well $[1,2]$. On the contrary, the progression and integration of effective photovoltaic cells are hampered by two primary aspects: efficiency and cost. Recently, research into more efficient and effective research in photovoltaics has resulted in the existing of emerging solar cells and enhanced conventional efficiency baseline designed CIGS solar cells $[3,4]$. New chalcopyrite materials accomplished greater than $24 \%$ efficiency from expanding thin-film solar cells with efficiencies larger than 10\% [5-7]. However, the electricity price is approximately one order of magnitude higher when related to commercial prices from current solar cells [8, 9]. In this regard, this study aims to explore the materials for solar cell development generally, and the recent technologies obtainable.

Photovoltaic cells are devices utilized for converting solar radiation into photovoltaic effects via electrical energy. The architecture is presented by photovoltaic cells based on two semiconductor areas with various electron concentrations. These materials can be kind $\mathrm{n}$ or type $\mathrm{p}$, even though the material is electronically neutral in both cases. Holes 
flow from electrons, and the $\mathrm{p}$ region from the $\mathrm{p}-\mathrm{n}$ junction via the $\mathrm{n}$ region when both the $\mathrm{n}$ and $\mathrm{p}$ regions come into contact. Additionally, the fixed ions produce an electric field near the junction in the opposite direction of diffusion, leading to an implication existing. At stability, the diffusion is adjusted with the implication existing so that the net existing is zero. A potential barrier, in this regard, is framed at the $p-n$ junction.

Previously, different types of semiconductor materials and technologies were introduced for designing solar cells at low cost and with high conversion productivity. Conventional solar panels fabricated from silicon crystalline wafer modules are bulkier, making transportation complicated. These are, fundamentally, large-sized solar panels observed with glass panels. A bulky and heavier solar panel needs a large space, and perhaps big rooftops, to balance such large solar panels and provide high power applications. In this article, solar cell research and improvement focusing on solar energy's efficient application is studied based on different solar cells. This study presents the existing state of the art photovoltaic cell technology concerning materials utilized for fabricating devices, its productivity, and related costs. A comprehensive comparative examination has been performed on the four solar cell generations to focus on the different architectures, materials and methods, and their benefits and challenges.

Theoretical physics of coatings and their applications are also discussed in this paper. Several approaches on both industrial and laboratory-scale levels have been reviewed for syntheses or fabrication of these coatings. This paper emphasizes the use of recent advances in the application of solar cell materials.

\subsection{Literature Review}

\subsubsection{Material Used in Solar Cells Development}

The solar cell's main material is silicon. Regarding the semiconductor material applied, these materials have the properties of intensifying the absorption of the sun. Solar cells are mainly combined into initial, second, and third age batteries. The original battery is a silicon wafer. The second-generation battery is a thin-film solar battery (cadmium telluride, amorphous silicon, and CIGS battery), applied in photovoltaic power plants. The third is coordinated photovoltaic constructions or small independent electrical structures [10]. The solar cell thin film involved durability, aging material nascent voltaic photography (various meager cinematic developments).

Table 1. Comparison of selected materials and their properties for solar cell efficiency.

\begin{tabular}{lccccc}
\hline Material & CuInSe2 & Ge & Ga & Si & CdTe \\
\hline $\begin{array}{l}\text { Category } \\
\text { Band Gap } \\
(\mathrm{eV})\end{array}$ & Direct & Indirect & Direct & Indirect & Direct \\
$\begin{array}{l}\text { Absorption } \\
\text { edge }(\mu \mathrm{m})\end{array}$ & 1.04 & 0.67 & 1.43 & 1.11 & 1.49 \\
$\begin{array}{l}\text { Absorption } \\
\text { Coeff }\left(\mathrm{cm}^{-1}\right)\end{array}$ & 1.19 & 1.85 & 0.87 & 1.12 & 0.83 \\
\hline
\end{tabular}

The third age unit has been checked and is not used for monetary purposes. No matter how expensive solar cell innovation is and how low productivity is, improvement in solar cell innovation is still sought due to the growing demand and the prospect of unlimited flexibility. Figure 1 presents the types of the different materials utilized for photovoltaic solar cell systems, comprising mainly of silicon, cadmium-telluride, copper-indiumgallium-selenide, and copper-gallium-sulfide. The photovoltaic solar cell systems are distributed into different types, as displayed in Figure 1. 


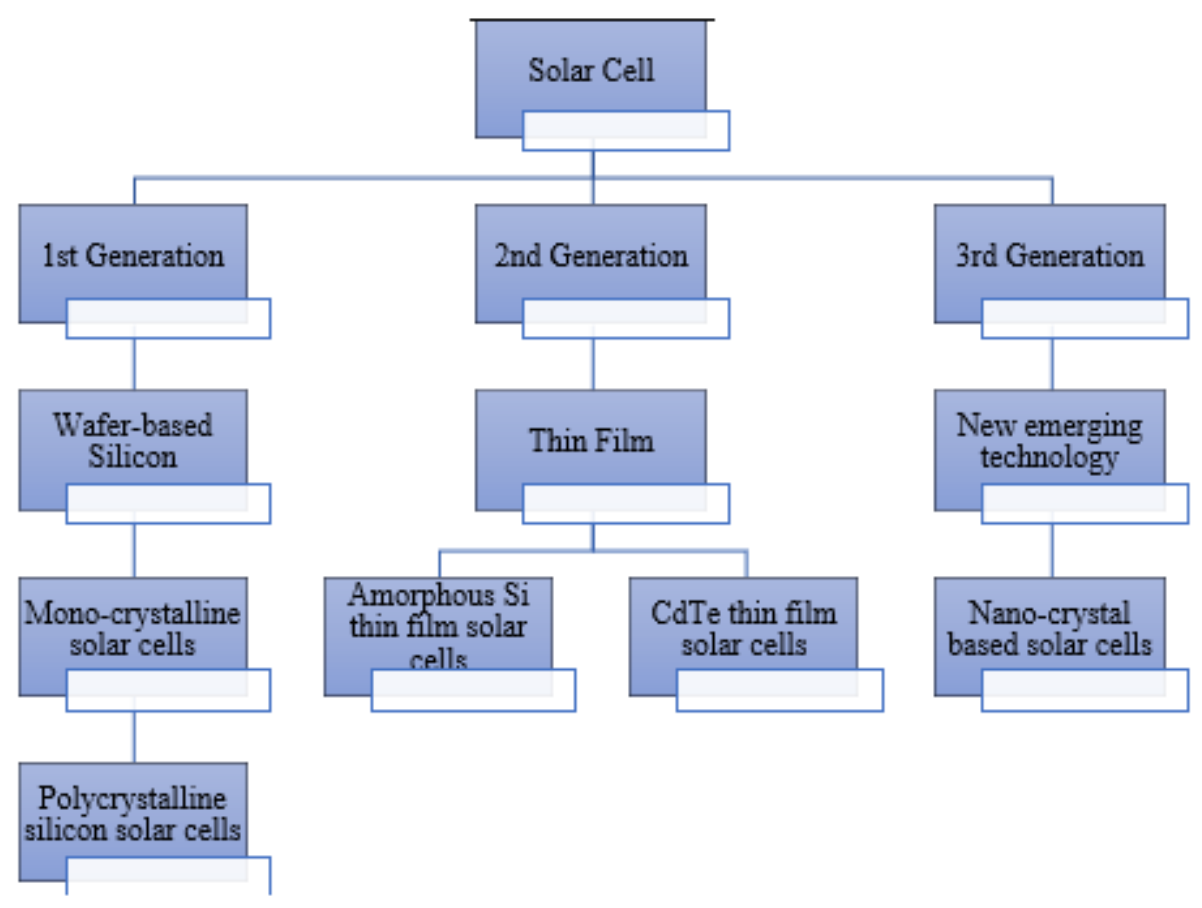

Figure 1. Solar Cell Classification.

\subsubsection{Monocrystalline silicon solar cell}

These solar cells are primitive solar cells and are named ordinary or ordinary solar cells. As the name suggests, these solar cells are made up of a single silicon gem. These silicone gems are cut from huge, hollow, round measured rods [11]. The strategy used to assemble these cells is called the Cheklausz measurement; the cell's edge looks like an octagon. These solar panels show a typical example, such as small white gems [12]. The productivity of these batteries is between $17 \%$ and $18 \%$. Figure 2 shows the production steps for the monocrystalline silicon surface. Fundamentally, the all-silicon wafer surface is degreased and cleaned. The wafer is ultrasonically washed, anisotropically digested, rinsed with deionized water, dried, and immersed in acetone, dissolving organic pollutants.

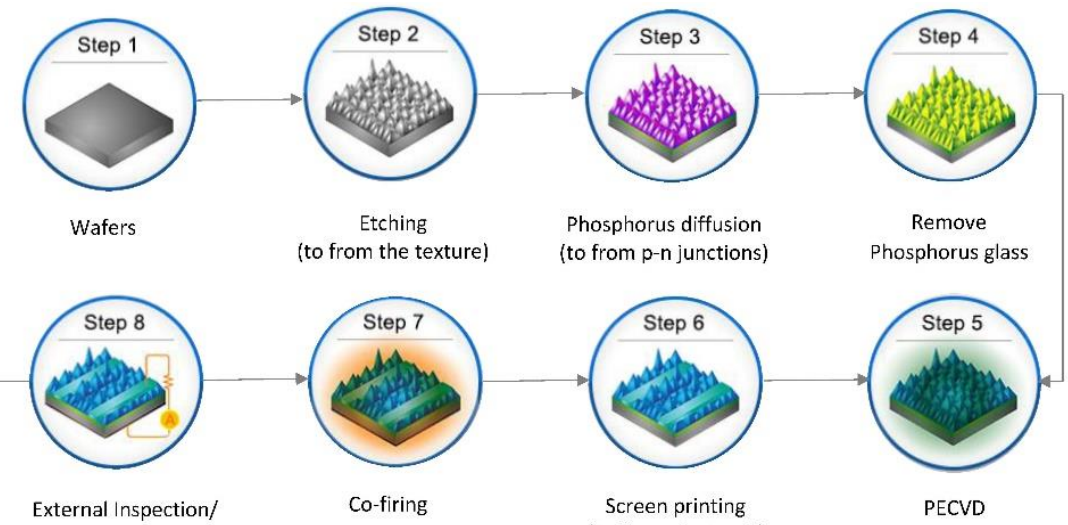

Output classification (to from electrode)

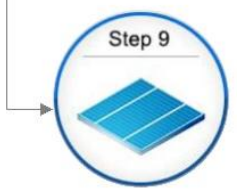

The finished products 
Figure 2. Monocrystalline Silicon Solar Cell [13].

\subsubsection{Polycrystalline Silicon Solar Cell}

Polycrystalline PV components are usually collected of various precious stones coupled together in a single cell. The battery is made using the cooling and hardening technology of the protruding candy cane, in which the assembly efficiency is very high [14]. In 2008, these batteries were the most used solar cells, accounting for $48 \%$ of total solar cell production, increasing their performance to around $12-14 \%$. Ribbon-shaped silicon is an example of a glass-like polysilicon solar cell [15]. This type of battery can usually reduce silicon waste, but productivity is low. Figure 3 shows the first commercial solar cells based on silicon wafer technology, including the elevating progress. At present, solar cell contribution is more than $1 \%$ of the global energy demand, which shows that the price per kWh must be mitigated to become competitive in more regions globally and acquire substantially higher market shares.
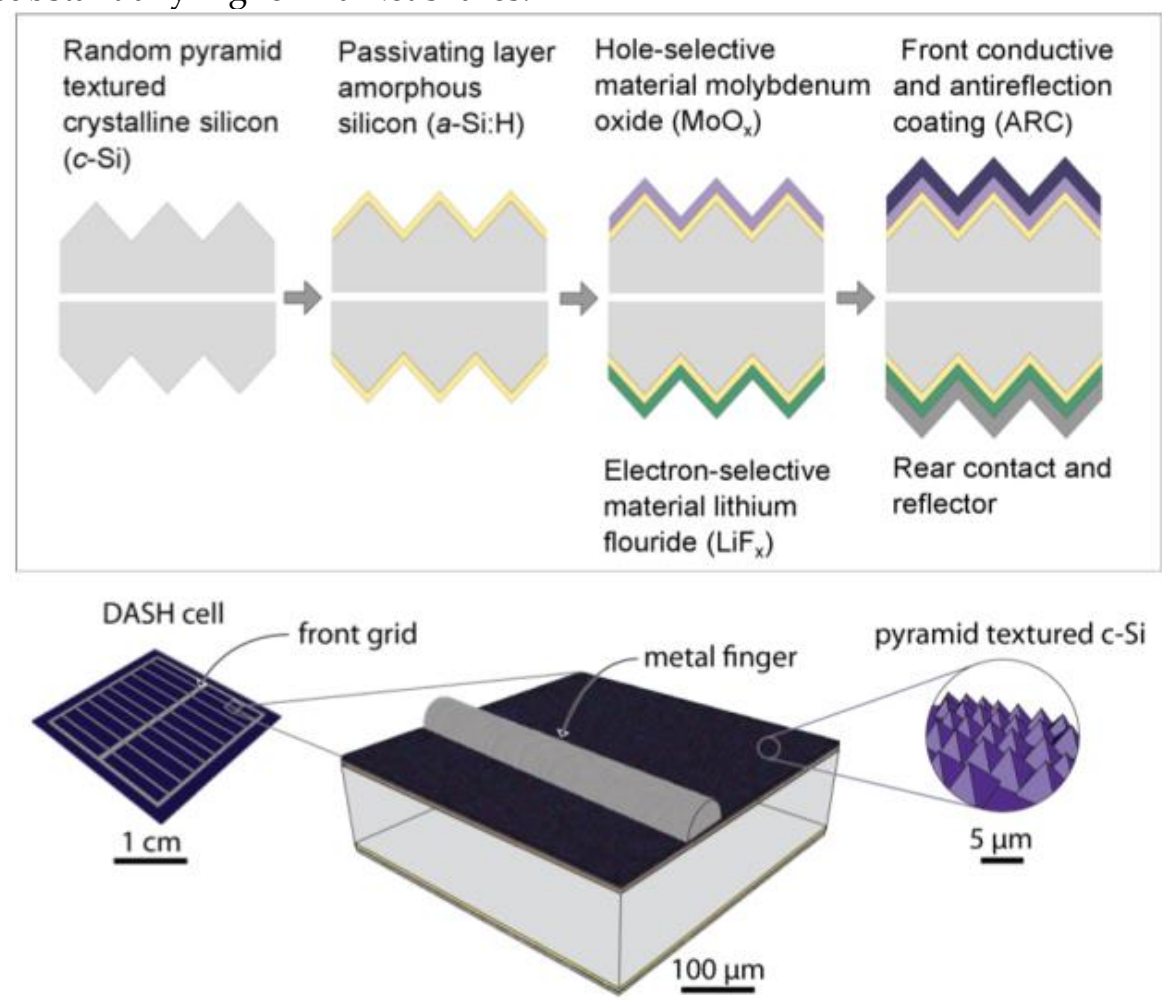

Figure 3. Polycrystalline Silicon Solar Cell [16].

\subsubsection{Second Generation Thin-Film Solar Cell}

Light film solar cells are identified as second-generation solar cells and are further practical than the original solar cells. These solar cells have an extremely thick, thin light retention layer, while the original silicon wafer cells have a light incident layer [17]. These advances have reduced the number of dynamic materials in the battery. This dynamic material is created as a sandwich between two glass sheets. Samples of such thin-film innovations are amorphous silicon, cadmium telluride (CdTe), and gallium indium copper diselenide (CIGS) [18]. Figure 4 shows the materials promoted different types for thinfilm solar cells. It was apparent that thin crystalline Silicon films represent the most used material of approximately $2.5 \mu \mathrm{m}$ thickness. Other candidates include cadmium tulleride and amorphous $\mathrm{Si}$, along with other thin-film materials. Modules for the second-generation have been promoted, but they have not achieved the first-generation solar cells' success because of module stability and technological issues. 


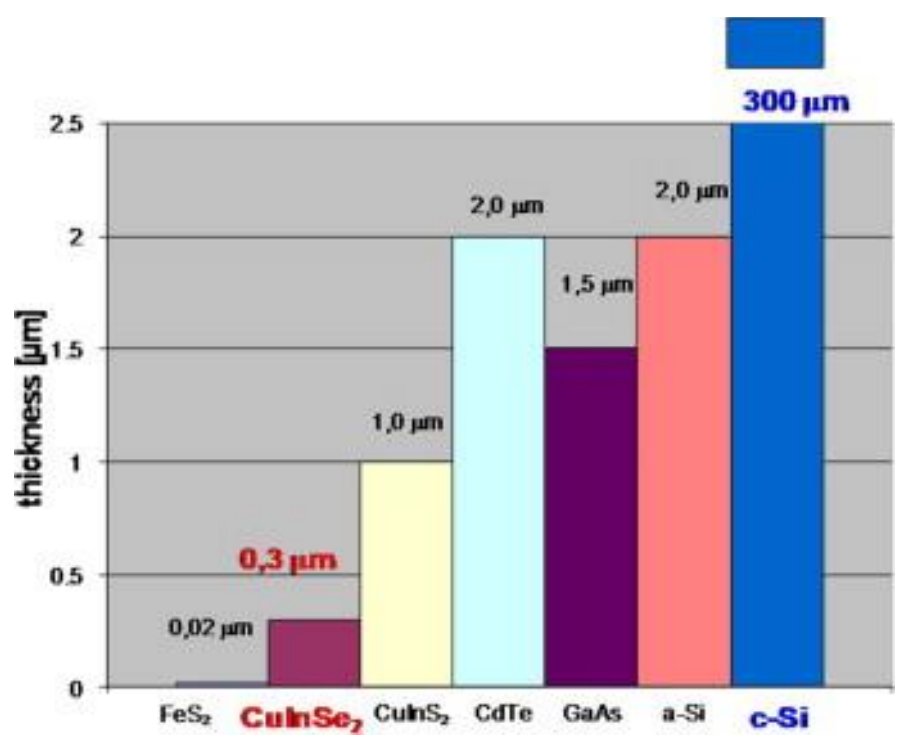

Figure 4. Thin-Film Solar Cell of Second Generation [19].

\subsubsection{Amorphous Silicon Thin Film Solar Cells}

Silicon solar cells are a sample of the best widespread innovation in thin-film solar cells. These solar cells were the first to be produced in a modern way. They can be produced at extremely low manufacturing temperatures, so different polymers and other laminated substrates can be used in moderation rather than other materials [20]. Therefore, these solar cells are very inexpensive and extensively used. The batteries are fabricated of miniature silicone, not glass or translucent. The aperture (1.7ev) of amorphous $\mathrm{Si}$ is larger than that of crystalline silicon [21]. The amorphous state here means that the silicon material contained in the battery has an apparent iodine effect in the opaque lattice structure. This is created by fixing the doped silicon material to the glass plate back using plasma-improved chemical vapour deposition (PICVD) [22]. The top cell is made of amorphous silicon, leaves, and absorbs visible light from the base cell area infrared part. The fundamental disadvantage of amorphous silicon solar cells is their instability, which has increased from $4 \%$ to $8 \%$. These batteries can be simply handled at high temperatures and are suitable for adverse weather conditions [23]. Figure 5 demonstrates the device-structure in the experimental section, along with the present density-voltage characteristics and the fabricated solar cell EQE spectrum.
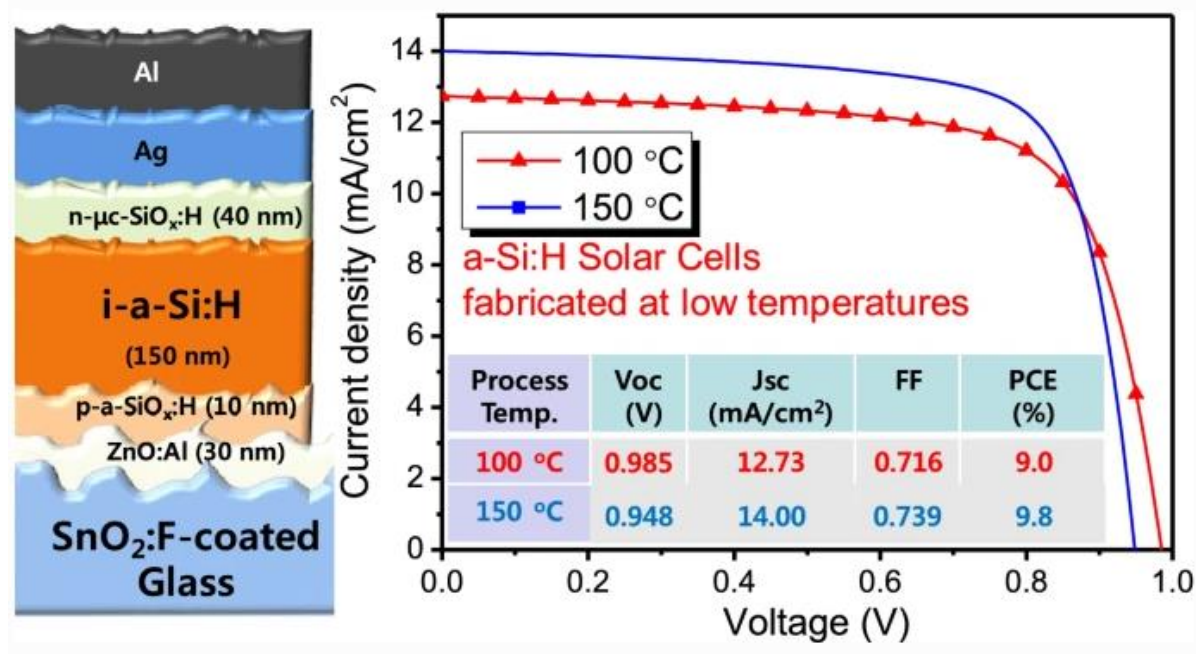

Figure 5. Thin Film Solar Cell of Amorphous Silicon [24]. 


\subsubsection{Cadmium Telluride Thin Film Solar Cell (CDTC)}

Cadmium is a dangerous substance, and the amount of tellurium is restricted. However, this is the right choice for the further development of the financial photo gadget. In terms of the cost of translucent silicon, this is the leading photovoltaic innovation to date [25]. These batteries have a gap of material close to $1.5 \mathrm{ev}$ and have high adhesion strength. Therefore, it is the most preferred material for the innovation of light, and thin-film solar cells. These batteries have tape holes that can absorb light more efficiently and increase their efficiency [26]. During the initial assembly of these solar cells, the CdTe -based solar cells are made of polyglass-like materials, and glass is selected as the substrate. Subsequently, various techniques can be used to cover the multilayer CdTe solar cells on the substrate [27]. This cycle is named education. These batteries are fabricated by sliding layers of tellurium between cadmium telluride layers to build on junction diodes. As mentioned above, CdTe has a gap size of about $1.48 \mathrm{ev}$ and a high absorption coefficient of $5 \times 1015 / \mathrm{cm}$, so the efficiency is between $9 \%$ and $11 \%$ [28, 29]. However, the use of these cells must also consider the climate because cadmium is a toxic component (accumulates in humans, organisms, and plants), and so their removal during assembly and after use is a big problem. Consequently, proper cadmium control and the natural hazards were associated with it limit the use of this innovation [30].

\subsubsection{Copper Indium Gallium Selenide (CIGS solar cell)}

Comparable amorphous silicon, and cadmium telluride CIGS solar cells are also an innovation involving thin-film solar cells. The CIGS layer is lightweight and adaptable so that it can be stored on an adaptable substrate. CIGS is a mixed quaternary transmitter medium containing four precise components: gallium, indium copper, and selenium [31]. These batteries have high applicability of about $10 \%$ to $20 \%$. The CIGS assembly is completed through the following procedures: the electrochemical masking strategy, printing, and electronic wave declaration. It is made by placing indium, gallium, thin copper layer, and selenium on glass or plastic casing next to the cathodes on the back, and front to assemble electricity [32]. The CIGS material substrate could be a polymer, glass plate, substrate, steel, or aluminum, and so on. It has a maximum retention factor and therefore requires a thinner film than any supplementary semi-directional material. The CIGS thinfilm solar cell's main feature is that its existence is delayed without extensive damage. Pie's weak solar cell film has deteriorated by about $15 \%$ and left the market base [33]. In 2013, the entire CIGS industry's share was only $2 \%$, and any potential negative film progress was $10 \%$. CIGS batteries continue to evolve because they ensure that silicon productivity can be easily matched.

Figure 6 represents a representation diagram of a categorized bandgap. A three-stage co-evaporation method was prepared using CIGS films based on a double-graded conduction band shape, with an in-depth notch point handier to the absorber front surface. A narrow bandgap is positioned at the notch point, and a varied bandgap is positioned at both sides such that: $E g_{3}>E g_{1}>E G_{2}$. 


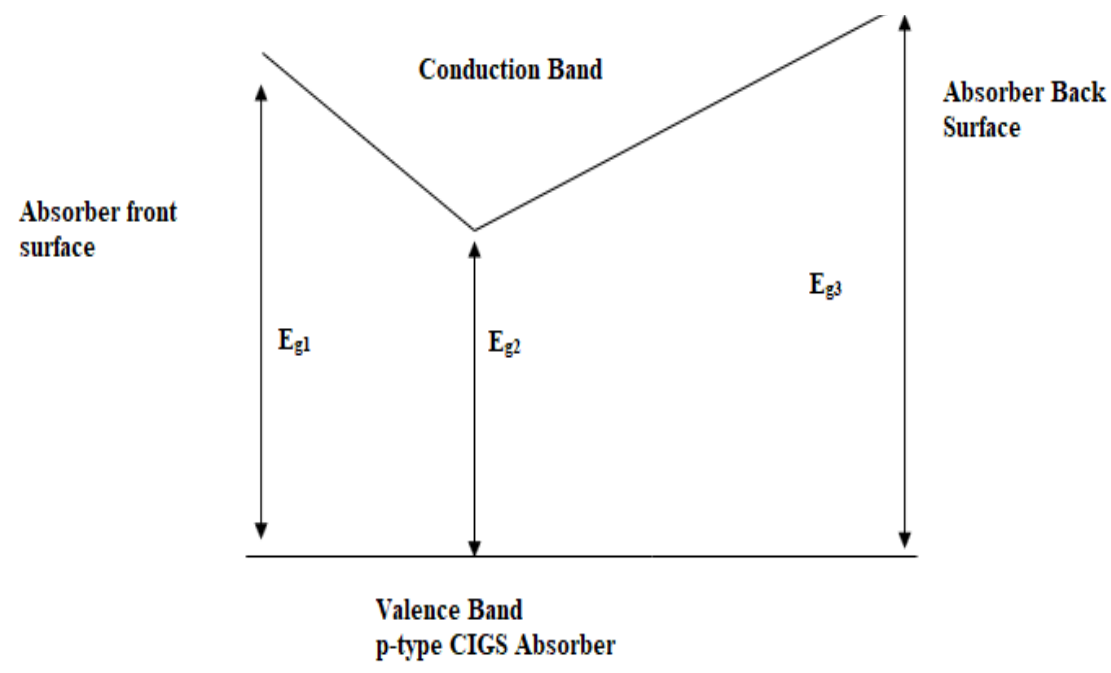

Figure 6. Solar Cells of Copper Indium Gallium Selenide.

\subsubsection{Third Generation Solar Cells}

Solar cells founded on nano-gemstones are often referred to as quantum dots. This is just the name of the quantity that flows within a few nanometers, such as absorbent silicon or porous $\mathrm{TiO} 2$ (titanium dioxide) [34]. There is the possibility that nano-gemstones will be used as moderate and successful solar cells. It is expected that nano-gemstones' form and size will be adjusted by absorbing light in the whole area. 3D control requires more remarkable information ionization, and results in transporters that produce various changes from a single photon [35]. The incarceration extends the thickness of the condition along the edge of the belt to some extent, as innovations to develop nano-gemstones focus on replacing materials like amorphous silicon, CIGS, and cadmium telluride solar cells [36].

These batteries are made by involvement nanomaterials in showers and coating them with $\mathrm{Si}$. In common compound semiconductor solar cells, when photons excite electrons, they form an electron pair. However, when photons encounter a small number of relatively semi-directional materials, different electron apertures can be modeled (in some cases, 2 or 3 plus 7 are usually seen) [37]. Because of its measurement capabilities, this type of clustering is cheaper to manufacture than other photography options. Compared to the assumed capacity of $44 \%$, these solar cells' productivity is only around $2.5 \%$. The natural coating's carrier portability reduces the solar cells' efficiency on the nanoscale [38].

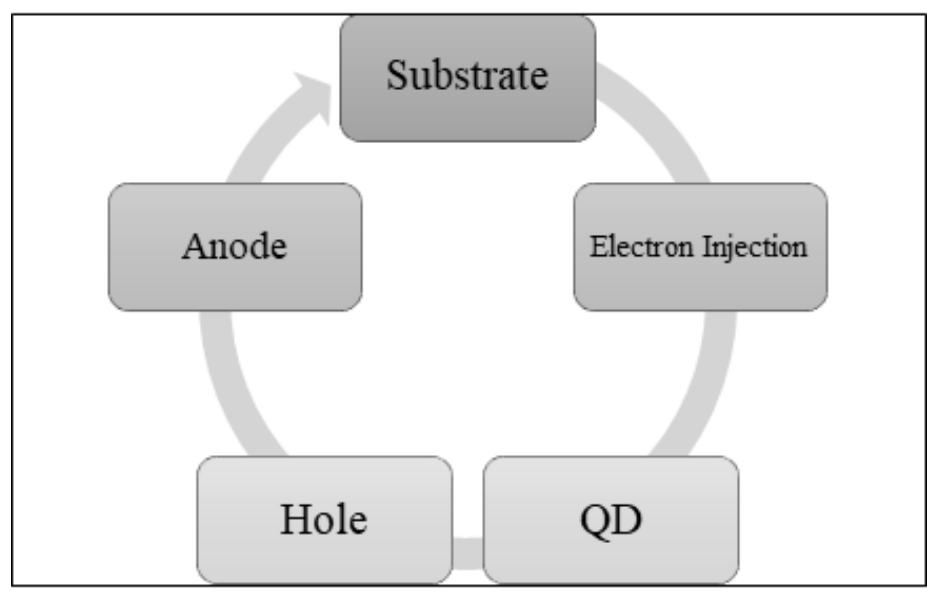

Figure 7. Nano-particles Material Schematic Diagram. 
These batteries have the advantage of adaptability due to their polymer materials. They consist of light-weight wear layers (usually $100 \mathrm{~nm}$ ) connected one after the other, which are laid on polymer films or strips $[39,40]$. The benefactor (polymer) and the acceptor (fullerene) are mixed. The materials that exist for this reason are polyphenylene vinyl, branched carbon fullerenes, and so on. Hegger, Shirakawa, and Mac Diarmid received the Nobel Prize in Science in 2000 for determining another polymeric material called lead polymer. Polymer solar cells are also divided into PU impact standards. They can be handled by liquid devices and provide basic scrolling functions for changing the print size [41].

Poly (2-methoxy-5- (2-ethylhexyloxy) phenylene vinylene) (PPV), C60, and its various minor blends could be applied to construct key polymer solar cells and realise a highperformance conversion effect. After careful study, they achieved PPY polymer solar cells' competitiveness over 3\% [42]. In 2011, the Massachusetts Institute of Technology and Michigan studied solar cells made with $2 \%$ competitiveness and $65 \%$ simplicity. At the California University in Los Angeles, scientists recently used a similar method to construct very similar polymer solar cells with $70 \%$ simplicity and $4 \%$ force conversion productivity. The productivity of energy changes previously achieved with conductive polymers is less than that of inorganic materials [43]. Even so, Konarka Power Plastic competence in 2012 was $8.3 \%$ and that of natural tendon cells 11.1\%. Fluid Gemstone (LCD)'s display capacity expanded, and an advanced reuse idea called Polarized Natural Photography (ZOPV) was developed. This uses an equivalent polarizer, photographic equipment, and an approved solar panel.

A series of phenomena will occur because of the association between the semiconductor materials and the electron beam, when a highly energetic electron beam is emphasized on the semiconductor. Initially, elastic scattering procedures backscatter the occurrence of primary electrons. This segment is approximately uniform for silicon at $10 \%$ in the energy range below $60 \mathrm{keV}$. The remaining primary electrons offer their energy to the semiconductor lattice through inelastic scattering procedures such as the generation of excess-hole pairs, generation of x-ray, and generation of secondary electrons. The following expression explains the dissipation of the occurrence of electron energy:

$$
E_{o}=E_{e h}+E_{S E}+E_{X}+E_{R E}+\cdots
$$

Where $E_{o}$ is the overall occurrence of electron beam energy; the energies utilized for generating excess electron-hole pairs, backscattered electrons, secondary electrons, and x-ray are represented through $E_{e h}+E_{S E}+E_{X}+E_{R E}$.. The energy loss in silicon is very minimal and can be avoided, so the energy used to produce excess electron-hole pairs is almost:

$$
E_{e h} \approx E_{0}-E_{R E} \approx(1-\gamma) E_{0}=0.9 E_{0}
$$

The electron-hole production pairs in silicon occur by influencing the ionization of the valence band electrons in the conduction band, which leaves holes at the valence band. The excitation may occur with reduced energies compared to the valence band edge at the different sub-valence band. The electrons can further be brought to different conduction band levels, which outcomes in the produced electron-hole pairs' kinetic energy. Therefore, the average energy $e_{i}$ needed to produce one electron-hole pair is superior to the bandgap energy $E_{g}$. The silicon lattice absorbs the generated carriers' kinetic energy because of lattice vibration, making electrons return to the conduction band minimum, and holes to the valence band maximum, also generating phonons. ei is approximately $3.6 \mathrm{eV}$ in silicon; therefore, the number $\mathrm{N}$ of generated electron-hole pairs can be anticipated as:

$$
N=\frac{E_{e h}}{e_{i}}=\frac{900}{3.6} E_{0}=250 E_{0}
$$


The production of carriers happens in a place called generation volume. The following empirical function can be used for the distribution of the produced electron-hole pairs by:

$$
N(z)=\frac{N}{d} \lambda\left(\frac{z}{d}\right)
$$

With

$$
\lambda\left(\frac{z}{d}\right)=\left\{\begin{array}{c}
5.69\left(\frac{z}{d}\right)^{3}-12.4\left(\frac{z}{d}\right)^{2}+6.21\left(\frac{z}{d}\right)+0.6 ; 0 \leq \frac{z}{d} \leq 1.1 \\
0 ; 0 \geq \frac{z}{d}, \text { or } \frac{z}{d} \geq 1.1
\end{array}\right.
$$

\subsection{Solar Cells Preparation}

Photovoltaics (PV) is a progressively developing field with its rapid technologies and expanding markets. The solar cell is the fundamental construction block of $P V$, and the cost of this element comprises a sizable portion of the budgeting of an entire PV system [44]. The development of high-efficiency PV modules is aimed at through thin film compound solar cell research programs that can be conducted on large-area substrates via high-throughput and low-cost processing techniques [45]. These devices are characteristically developed on polycrystalline absorber layers with thicknesses in the 1-10 range. I-III-VI2 and CdTe ternary and multi-notaries are amongst the polycrystalline compounds formed as absorber layers for the thin-film of high-efficiency solar panels. These semiconductors are specifically attractive for a solar cell of the thin-film applications due to their high visual absorption quantities and their versatile visual and electrical features, which can be fabricated and tuned to meet the requirements of a predefined device configuration [46].

The solar cell researcher is provided with the I-III-VI2 ternary compounds and their quaternary and pendency solid solutions with an array of optical bandgap values varying from $0.96 \mathrm{eV}$ to $3.49 \mathrm{eV}$. The classical structure of high-efficiency I-III-VI2 compound solar cells is presented. For this device, the most used substrate is a (Mo) glazed soda-lime glass sheet [47]. The p-type absorber film is placed over the Mo layer, which performances as the back ohmic surface to the cell. The rectifying junction is established among the n-type window layer and the absorber film, comprising of either a thin structure or a thick film. The solar cell is accomplished by placing metallic grid trends over the window layer if required. The absorber layer is the heart of the solar cell configuration [48]. The optical and electrical properties of I-III-VI2 compound films have majorly relied on their defective chemistry and structure and stoichiometric composition, which are, consequently, majorly associated with firm growth indicators. Therefore, the processing approach's selection is essential to obtain compound films that possess high-efficiency solar cells.

\subsection{CIGS Layer Solar Cells}

Solar cell fabrication costs per kilowatt can be reduced based on the promising role of Copper Indium Gallium Selenide (CIGS), which facilitates solar cells competing with existing power production technology. High-efficiency CIGS solar cells can be formed up to a bandgap of approximately $1.2 \mathrm{eV}$. The point is to use a higher open-circuit voltage, and a reduced temperature coefficient [49]. Recently, there have been substantial enhancements in CIGS solar cell efficiencies. In particular, the highest energy conversion efficiency was achieved through the CuIn1-xGaxSe2 (CIGS)-based solar cells among PV thin-film materials. Those solar cells are fundamentally made from CIGS, which allows representing low Ga content, and results in absorber energy band gap values [50].

CIGS solar cells are complex thin-film solar cells, and the supreme ascertained alternative to silicon solar cells. Recently, solar conversion productivities of approximately 
$20 \%$ have been accomplished in CIGS solar cells. The buffer layer is the furthermost significant factor for influencing the conversion efficiency (Figure 8). On the contrary, the buffer layer structure and its actual effect have not been clarified for conversion efficiency.
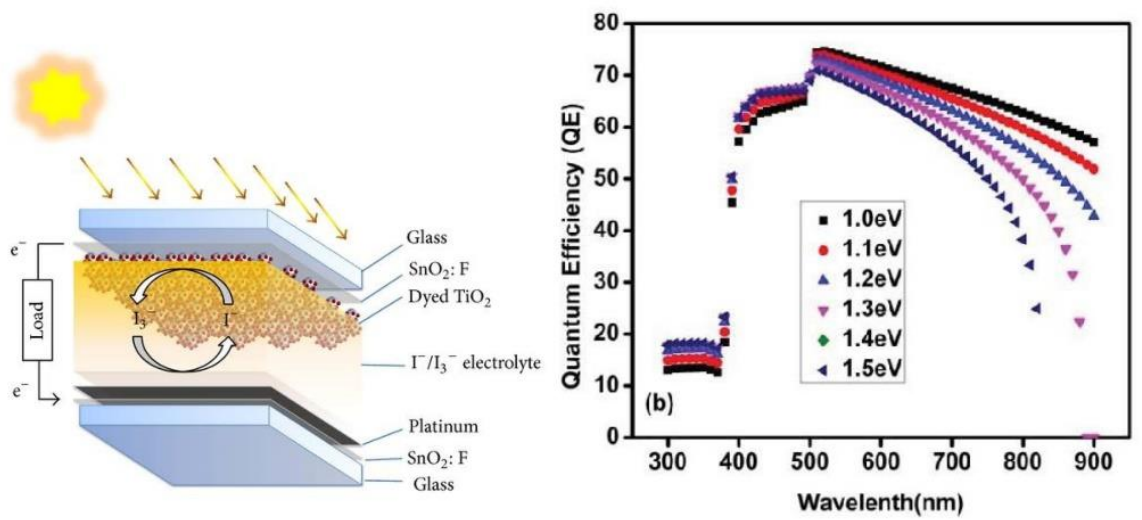

Figure 8. CIGS Layer Solar Cells with quantum efficiency of SnO2 layers.

Besides, some researchers have indicated how to achieve maximum solar cell performance. The optimum composition can be identified as having an atomic ratio of 0.088 absorbers in their bandgap and other device parameters. CIGS solar cells produce a current via a p-n junction like that of silicon solar cells [51]. There is a positive charge in the p-type layer because of the holes in its structure where electrons are missing, whereas the n-type layer has a negative charge because of an excess of electrons. The CIGS material is the p-type layer in a CIGS solar cell. The n-type layer comprises cadmium sulfide covered by transparent showing oxide layers, such as aluminum-doped zinc oxide and intrinsic zinc oxide [52].

It is witnessed that CIGS is the primary layer that determines the properties of the junction as well as device performance. Its development tends to be the core obstacle facing manufacturing, since the highest performance CIGS needs a complicated combination of increased temperature, controlled composition, the four features' reaction, and extended deposition times [53]. It has also been revealed that the enhancement of cell performance can be accomplished by Zn doping after CIGS development. In addition, it has been indicated that SIMS, QR, and JEQIC measurements can be doped on the CIGS layer by $\mathrm{Zn}$ evaporation, and that the conversion occurs at the surface from p-type to n-type.

\subsection{Methods and Techniques 2.1 Sputtering Method}

Sputter deposition is a physical vapour deposition approach for sputtering a thin film deposition. This encompasses material from an objective that is a source placed onto a substrate such as a silicon wafer [54]. Throughout the deposition process, sputtering is the re-emission of the deposited material by atom bombardment or ions. Wide energy distribution in sputtered atoms ejected from the objective is fundamentally up to tens of eV $(100,000 \mathrm{~K})$ [55]. The sputtered ions can characteristically fly from the objective in straight lines and energetically influence the vacuum chamber or the substrates [56]. In particular, the gas atoms are collected with the ions that act as a moderator and transfer diffusively to reach the vacuum chamber wall or substrates and condense after experiencing a random walk [57]. The broad range from high-energy effect to low energy thermalized motion is accessible by altering the background gas pressure. The sputtering gas is typically an inert gas, including argon. The sputtering gas' atomic weight must be closer to the target's atomic weight for gaining effective momentum transfer, so neon is preferable for sputtering light elements. In contrast, xenon or krypton are used for heavy elements [58].

Compounds can be sputtered through reactive gases. The multiple sputtered can be established on the targeted area, on the substrate, or in-flight, relying on the progression 
parameters. The obtainability of numerous parameters makes it a complicated process for controlling sputter deposition but further facilitates a high control level over the solar cells' microstructure and development [59]. Sputtering is comprehensively utilized in the semiconductor industry for depositing in different thin-film materials in combined circuit processing. Sputtering further deposits thin antireflection coatings on glass for optical applications [60]. Sputtering is the ultimate method for depositing contact metals for thinfilm transistors due to the low-substrate temperatures.

Molybdenum thin films were placed on soda-lime glass substrates under different coating circumstances through a DC magnetron sputtering device, as demonstrated in Figure 9. The Molybdenum sample was placed in an argon gas atmosphere through a base pressure of approximately 4 × 10-6 Torr. The substrate's rotation and substrate-to-target distance were positioned at $85 \mathrm{~mm}$ and $10 \mathrm{rpm}$ about the vertical axis, respectively. The aim was pre-sputtered for 5 minutes to eliminate any contamination before coating, and the substrates were ultrasonically prepared in acetone, dried in nitrogen, and rinsed with deionized water.

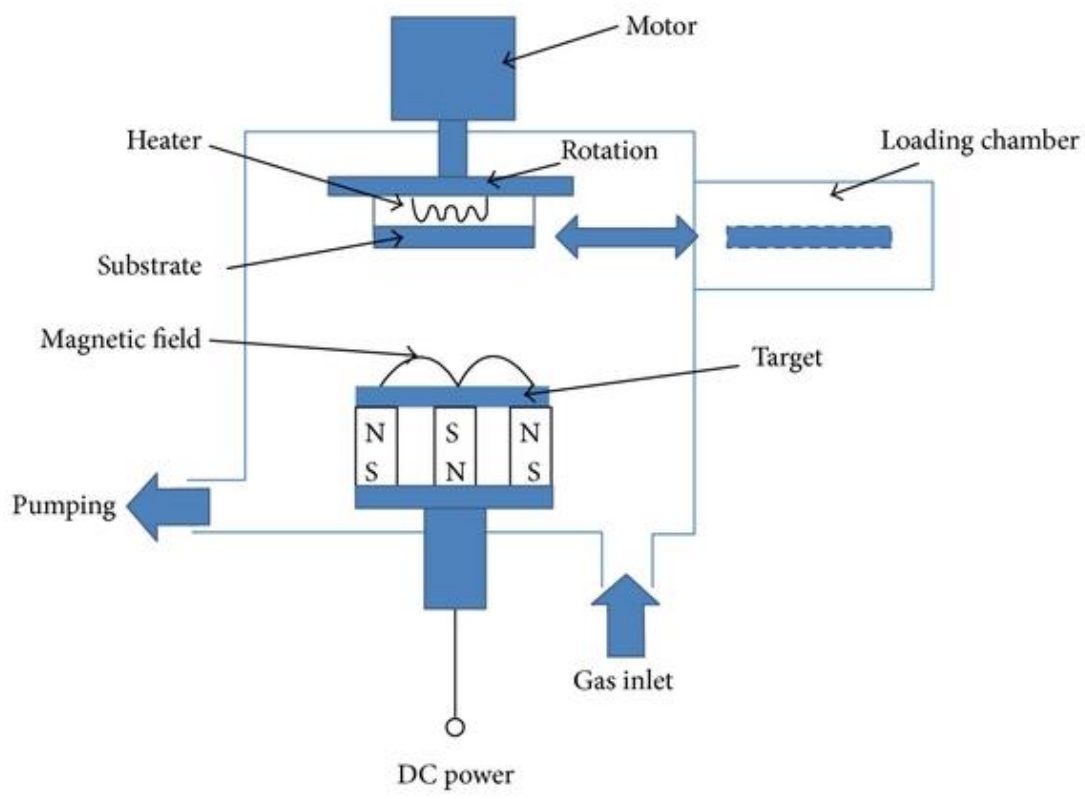

Figure 9. Sputtering System of the DC Magnetron Antireflection Coatings Sputtering System.

\subsection{Dye-Sensitized Solar Cells}

Dye-sensitized solar cells (DSSCs) have emerged economically and technically for p$\mathrm{n}$ junction photovoltaic devices. It has been reported that illuminated organic dyes could be used to generate electricity in electrochemical cells [61], with spinach (photosynthesis) used to extract chlorophyll. Initially, a chlorophyll-sensitized zinc oxide electrode was produced in 1972. Moreover, photons were converted into electricity via the electron injection of excited dye molecules into a semiconductor wide bandgap [62]. A DSSC comprises four fundamental parameters: the working electrode, redox-mediator, counter electrode, and sensitizer [63]. DSSC is the construction of a working electrode saturated with a sensitizer or a dye and sealed to the counter electrode saturated with a thin electrolyte layer through the assistance of a hot melt tape to avoid any electrolyte leakage (Figure 10). 


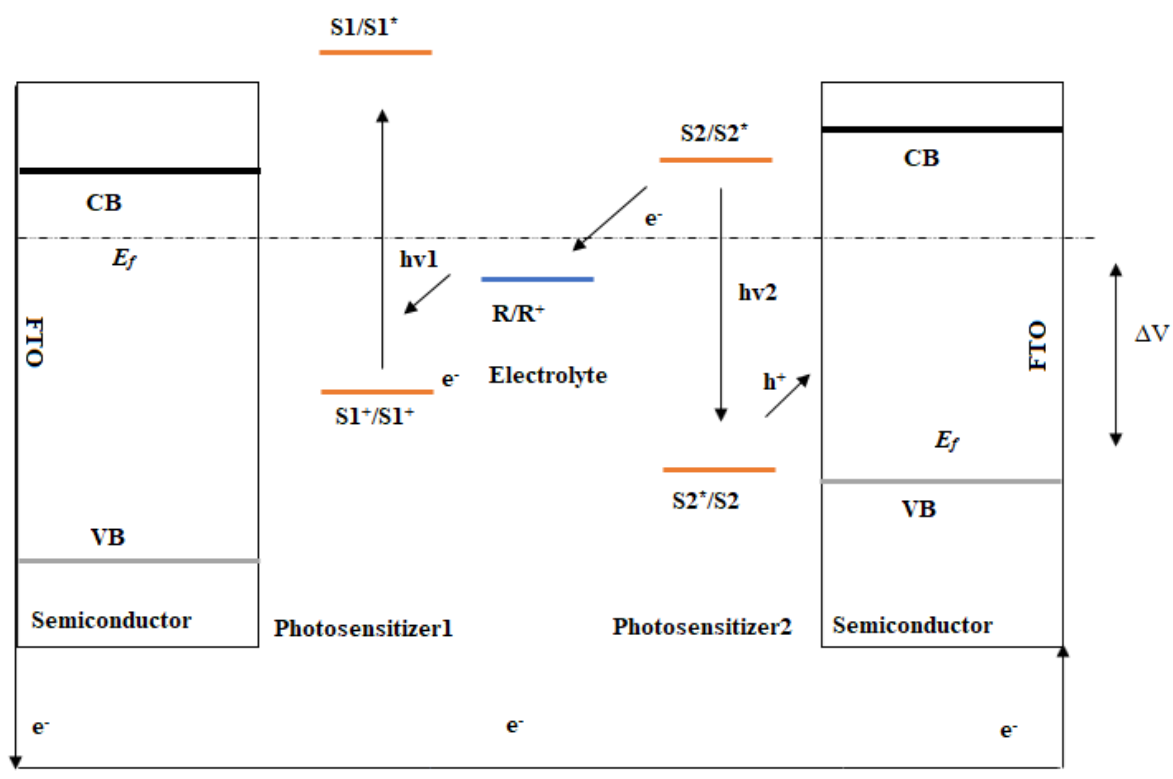

Figure 10. Illustration principle of Dye-Sensitized Solar Cells.

There are several attractive features in the DSSC, and it is straightforward to use traditional roll-printing techniques. Practically, it has been proven to eliminate several costly products, most significantly, ruthenium and platinum. However, the liquid electrolyte presents a severe challenge in making a cell appropriate for all-weathers [63]. The price/performance ratio of DSSC must be sufficiently relevant to consent them to participate with fossil fuel electrical generation by accomplishing grid parity, even though its conversion the efficiency is less than the best thin-film cells [64]. Due to chemical stability issues, commercial applications are predicted to contribute towards renewable electricity generation substantially.

\subsection{Doctor blade Technique}

Doctor blading, also represented as blade coating or knife coating, is a well-established thin-film fabrication method. It encompasses either moving a substrate underneath the blade or running a blade [65]. There is a minimal gap that demonstrates how many solutions can get through. The ultimate thickness is a fraction of the gap between the blade and the substrate, and thus it is affected by the viscoelastic properties of the solution and coating speed [66]. Doctor blading is a method that is well-absorbed for large-scale coatings. The approach has been further well-established to create thicker films from a viscous solution. However, it cannot provide the nanoscale uniformity or extremely thin films covered by spin coating [67]. On the contrary, this approach's simplicity, scalability, and versatility make it accurate for solar cell preparation. It is further used across various research fields such as thin electronics, paints, ceramics, and battery technology [68].

Figure 11 illustrates the $\mathrm{TiO} 2$ thin films micrograph arranged by modified and traditional doctor-blade methods. A perfectly smooth shape is represented through the $\mathrm{TiO} 2$ thin film designed with an improved doctor-blade, which can be based on the occurrence of lubricating oil. The oil prevents quick evaporation of water in the $\mathrm{TiO} 2$ throughout the computation process. Nonetheless, several micro-cracks occur on the $\mathrm{TiO} 2$ thin film surface arranged using the traditional doctor-blade method. These macrocracks will reduce the entire conversion efficiency of dye-sensitized solar cells (OSSC). Figure 12 presents the solar cell structure and the solar cell flow diagram fabrication process. The subsequent thin film layers of the solar cell were arranged, and this is described next. 


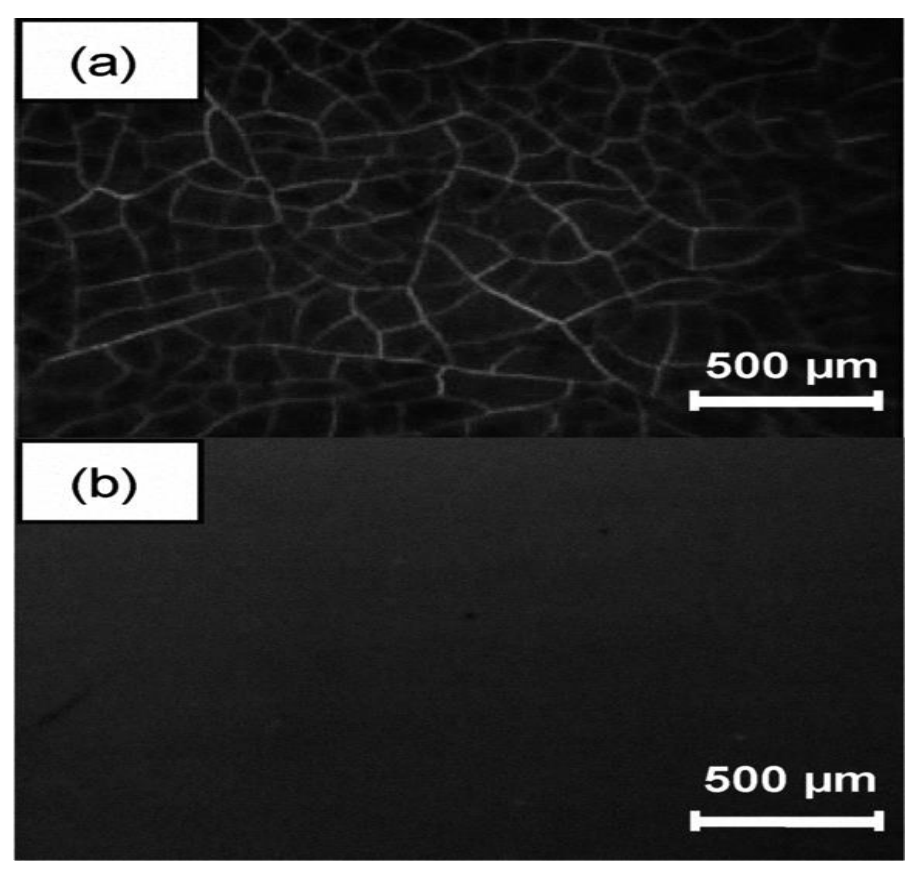

Figure 11. The Ti02 thin films micrograph prepared by (a) conventional and (b) improved doctor-blade methods [69].

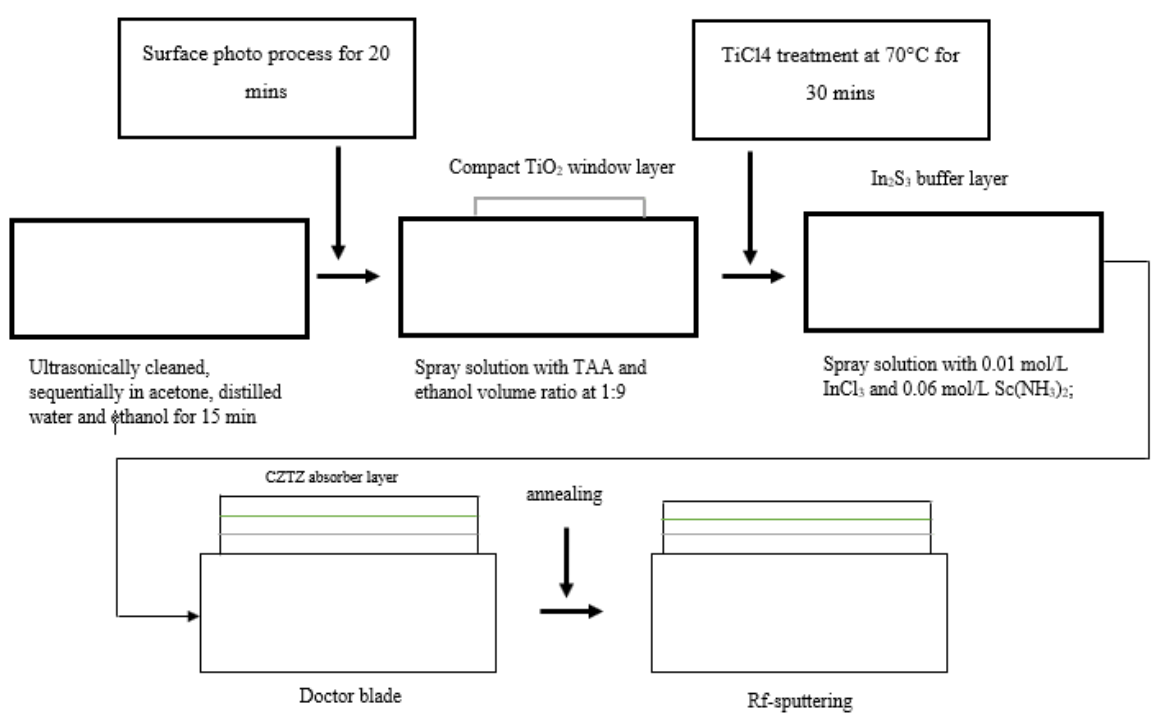

Figure 12. Doctor-blade Technique.

\subsection{Spin coating Method}

The spin coating solution is dispensed onto a flat substrate, which begins to rotate or is ready to rotate. The solution is sheared by the centripetal force, which causes it to be distributed consistently across the exterior as a thin film [70]. The shearing force applied determines the deposited film's thickness, which is comparative to the rotational rate. Uniform films are produced through spin coating, reliably and instantly, over a small surface area [71]. It is accurate to be used in research and development laboratories working on a minimal surface area. Besides, spin coating is efficient and easy to set up and use, making it a popular method across various research fields. It is usually utilized to process photoresists on wafers and for thin electronic devices [72].

Lastly, some washed FTO glasses were used as substrates for collecting powder from a burning candle as spongy carbon counter electrode. The soft carbon fibers materials/FTO 
composite counter electrode was then hard-pressed on the Spiro-OMeTAD layers of incomplete devices. The entire process was conducted in air conditions with a comparative humidity of up to $23 \%$ at room temperature. The overall preparation process is presented in Figures 13 and 15 below.

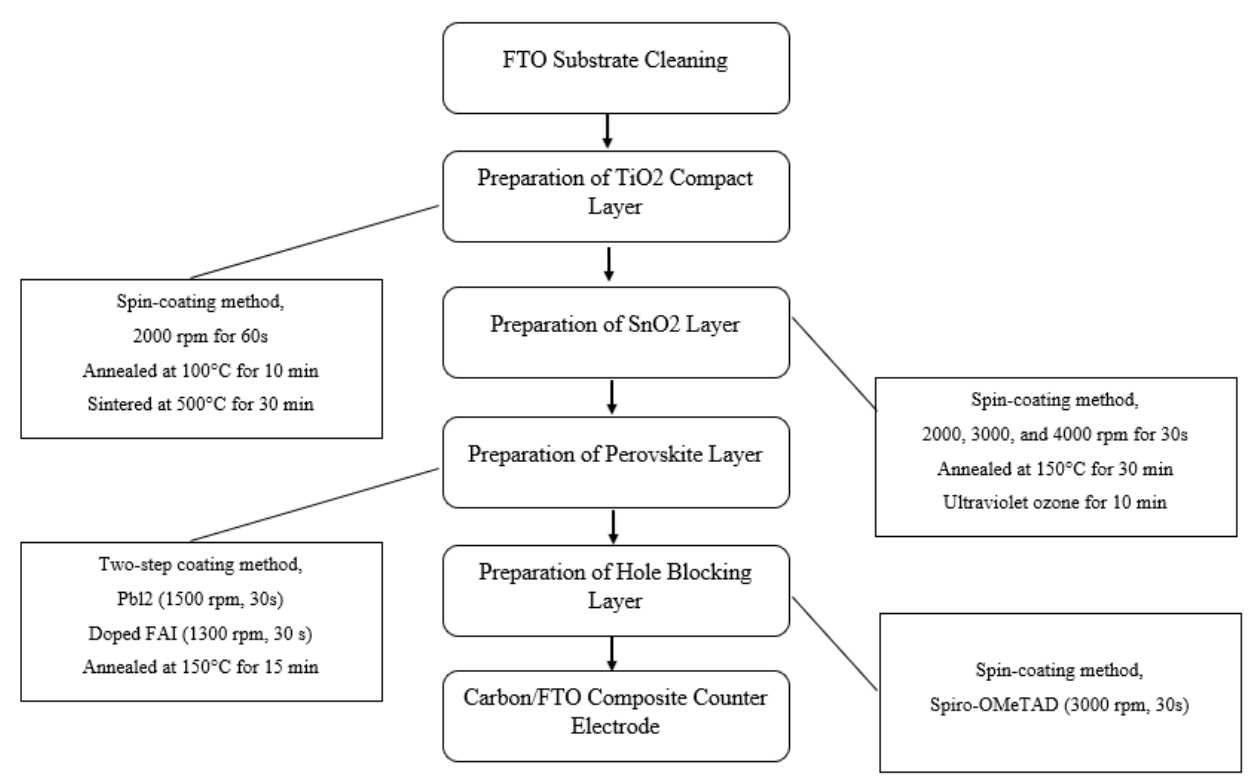

Figure 13. Working Principle of the Spin-Coating Method.

\subsection{Solar Cell Properties}

\subsection{Ultra-high Band Gap Solar Cells}

The Selenium (Se) photoconductivity was exposed by Willoughby Smith in 1873 [73]. The first solid solar cells were created 10 years later by Charles Fritts by coating metal foils with thin gold and Se layers. Modern science and technology rendered the propagation of the photoelectric result and other essential phenomena. This also led to the Nobel Prize work that includes sensors, machines, rectifiers, and other technologies. The rapid expansion of the silicon microelectronic industry led to a decline in SE research by offering highquality material with bandgap. Still, the bandgap is most suitable for single-junction solar cells, and science and technology are likely to benefit from the development of silicon for integrated circuits that propel silicon photovoltaic devices. The efficiency of this device ranges between 6 and 26.6\% [74]. On the contrary, in initial demonstrations, less than 1\% was achieved, culminating in 5\%. Significant growth in the silicon photovoltaic industry has reduced module prices and costs, which has further helped achieve good module efficiency of $24.1 \%$ [75]. Increased conversion efficiency is enabled by passivation, material quality, and improved device structure. Additionally, this approach is likely to limit the practicability for Si single junction. The most realistic part of tandem solar cell architecture with several bandgaps is offered by higher photovoltaic efficiencies that surpass single junctions' limitations.

At present, the limitation is imposed on the multi-junction cells for expensive semiconductor photovoltaic and low-efficiency silicon materials. Sophisticated solar tracking concentrator systems are required by these devices, which are not useful for mainstream disposition compared to planar Si modules. An efficient high-Eg top cell lacking is considered a significant challenge to making effective and low-cost tandem PV devices for large-area applications. This process is compatible with the creation of a lower $\mathrm{E} \mathrm{g}$ absorber. The planar tandem photovoltaic devices research was reinvigorated by metal-organic hybrid perovskite materials offering high-efficiency solar cells with high tunable band gaps being treated at low temperatures [76]. The examination for stable and fewer 
toxic substitution is motivated by concerns regarding long-term stability and heavy metal content.

Depending on the fabrication conditions, Trigonal selenium is reported $\mathrm{Eg}$ between 1.83 and $2 \mathrm{eV}$ [73], which is likely to be processed at temperatures under its around $220{ }^{\circ} \mathrm{C}$ melting point. This condition is an ideal triple-junction photovoltaic device, as well as a top absorber in monolithic tandem [79]. The Se solar cell reported in 1985 utilized n-type TiO2, dumped on SnO2: F (FTO) coated glass. There is a further similarity between this structure and some current hybrid perovskite solar cells, while an innovative holetransport layer is completely ignored [77].

Recombination is likely to be reduced, and collection can be improved by introducing a consistent inorganic $\mathrm{MoO}$ x high-work-function hole-selective layer between the selenium and the gold back [78]. Moreover, the selenium absorber thickness is reduced to only $100 \mathrm{~nm}$ to escalate the back-surface field's advantage and decrease fabrication time and material consumption. There is the optimization of a tunable bandgap $\mathrm{Zn} \times \mathrm{Mg} 1-\mathrm{x} \mathrm{O}$ $(\mathrm{ZnMgO})$ buffer constructed on the field of chalcogenide photovoltaics with combinatorial experiments for producing a measured open-circuit of $969 \mathrm{mV}$ voltages. However, there is a need to improve voltage in these cells as it is nearly $700 \mathrm{mV}$ lower than the Shockley-Queisser (SQ) limit for the (Se) bandgap (1.95 eV).

In this early semiconductor, other fundamental phenomena broadcast and the photoelectric effect via modern science and technology, led to the sensors and rectifiers, and photocopy machine, among other technologies [80]. Selenium investigation failed in the face of the appearance of the promptly increasing silicon microelectronic manufacturing, which provided a high-quality material with a bandgap and adequate single-junction solar cell. The silicon advancements for combined circuits led to both the technology and science that drove silicon photovoltaic device the efficiency from approximately $6 \%$ to $27 \%$ today $[81,82]$. On the contrary, less than $1 \%$ of Se was accomplished in the earliest studies, and it culminated at $5 \%$ in the 1980s. After the silicon PV industry was developed, production costs as well as module prices were mitigated, rather than accomplishing an effective module efficiency [83, 84]. Material quality and passivation have allowed improved conversion efficiency, although enhancements are required to reduce Si angle junction's practical restrictions in these areas.

Up till now, expensive III-V semiconductor photovoltaic and low-efficiency amorphous silicon materials have been restricted by multi-junction cells. These devices need adequate solar tracking concentrator systems and have shown modest useful usage for mainstream applications compared to planar Si modules. A core issue for constructing low-cost and efficient tandem PV devices has been the efficient high- $E g$ top cell lacking that is process compatible for fabricating reduced $E g$ absorbers. More recently, the research into planar tandem photovoltaic devices has been reinvigorated by metal-organic hybrid perovskite materials, which provide high-efficiency solar cells with high bandgaps that could be processed at low temperatures [73, 76, 85-87]. On the other hand, issues regarding the lasting stability of such compounds and their heavy metal contented have encouraged the examination for more stabilized and less toxic options.

\subsection{Self-Cleaning Superhydrophobic Coatings}

Most people are not aware of the word "superhydrophobic." Water drops do not stay on superhydrophobic surfaces but roll-off. The lotus leaf's low surface energy and its rigid nanostructure/hierarchical micro/ result in extreme non-wettability. Water is disabled by the air trapped inside the rigid protrusions for impregnating, maintaining a stable liquidair interface with a reduced interface to minimum solid fraction [88]. Dust is compiled from rough superhydrophobic surfaces by the rolling drops, unlike the normally smooth glass-like surface. Most individuals are attracted to the cleaning ability of superhydrophobic surfaces, and it is possible to apply this cleaning technique to daily activities such as the body of vehicles, as well as skyscrapers, fabrics, metals, sponges, marbles, windshields, glass windows/doors, solar cell panels, sports shoes, papers, and woods [89-91]. 
As the name proposes, such materials are certainly cleaned by a natural water stream, including rainfall, which substantially mitigates routine maintenance costs. Self-cleaning is widespread in nature; for instance, the lotus plants leave, butterfly wings, rice plants, fish scales, etc. These naturally occurring superhydrophobic coatings portray the lotus effect and their individual properties, as shown in Figure 14.

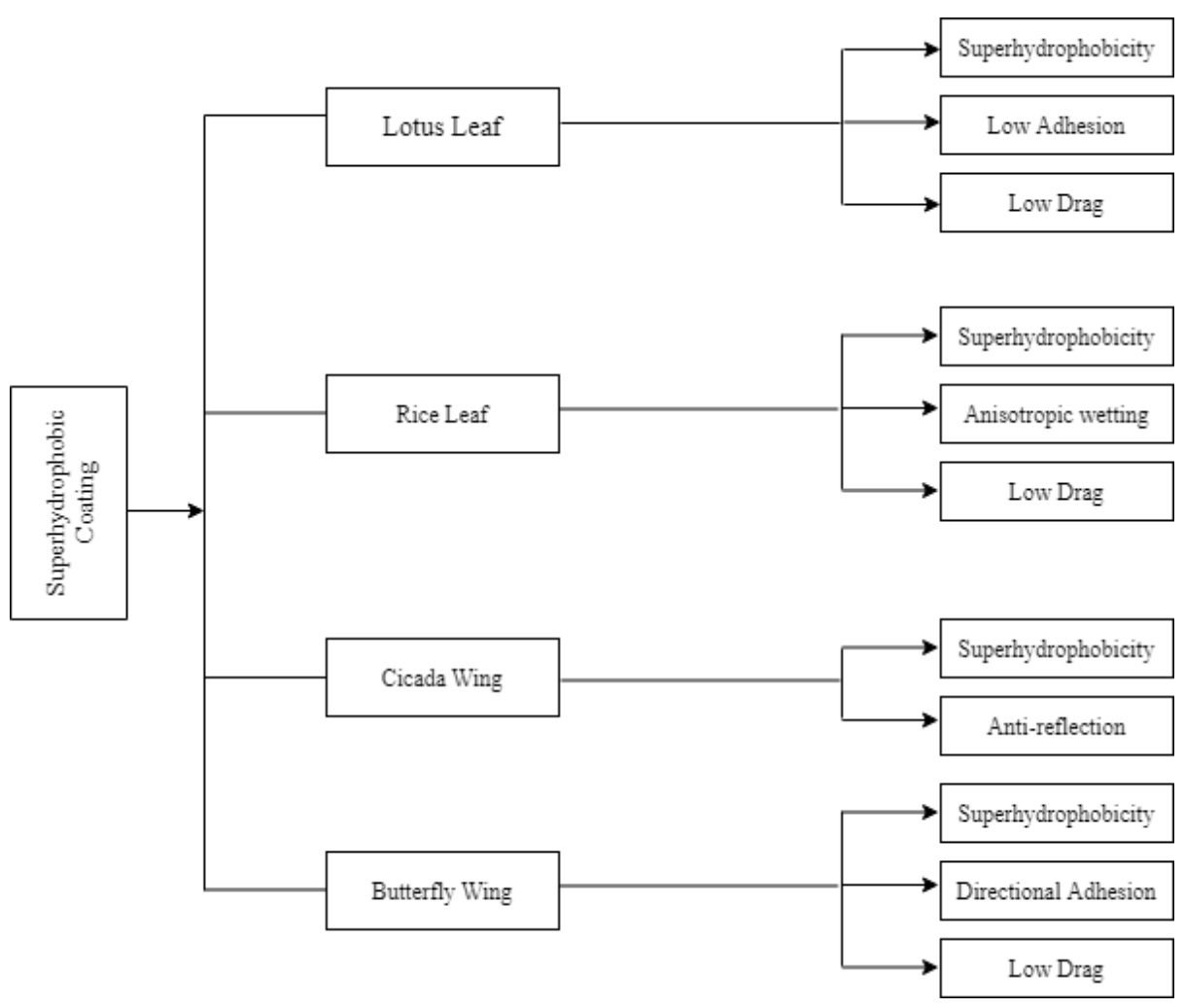

Figure 14. Self-Cleaning Superhydrophobic Coatings [92].

There has been an increased demand for transparent and durable superhydrophobic coatings in the industrial sectors. $\mathrm{Xu}$ and He [93] used modified hollow silica nanoparticles to prepare a highly transparent superhydrophobic coating on the glass. After modification, hollow silica nanoparticles were dipped and coated glass substrates. The chemical vapour deposition of perfluorooctyltrimethoxysilane completed the post surface chemical modification. It has been shown that Liu et al. [94] obtained a transparent superhydrophobic film on the glass substrate through a simple coating by using the sol-gel processing of long chains. Another study by Xu et al. [95] modified silica nanoparticles on glass by preparing a transparent superhydrophobic coating through simple spin or dip coating. Superhydrophobic polyester fabrics and cotton were prepared by Gao et al. [96] through the deposition of the surface modification and silica sol using hexadecyltrimethoxysilane (HDTMS). The preservation of the superhydrophobicity of fabrics is possible for up to 30 laundry cycles. Xue et al. [97] depressed the cotton fabric surface energy by depositing $\mathrm{TiO} 2$ sol using stearic acid to accomplish superhydrophobicity. This superhydrophobic cotton fabric exposed satisfactory UV shielding characteristics. 


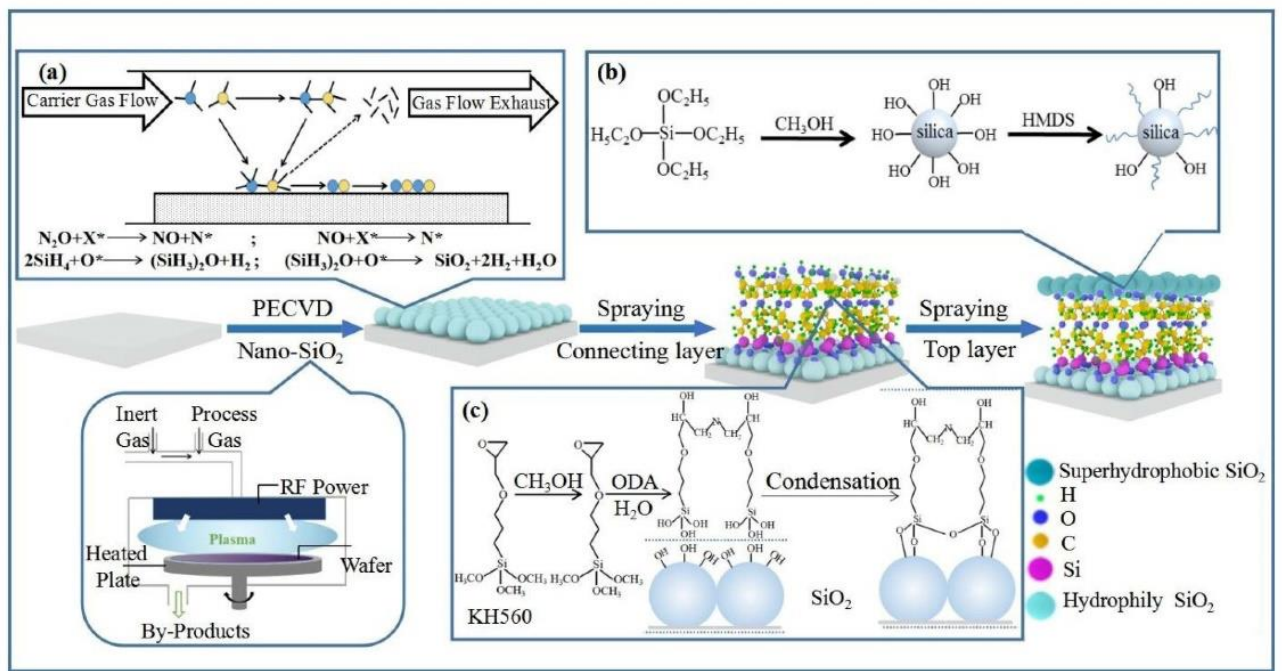

Figure 15. The superhydrophobic coating preparation process [136].

Superhydrophobic coatings assist in the initiation of metallic corrosion, which is a huge challenge. For instance, the single-step electrodeposition technique was adopted by Wu et al. [98] to guarantee a hybrid silica sol-gel film on mild steel. It is possible to achieve superhydrophobicity by excellently modifying the deposition potential and allowing time to reveal enhanced corrosion resistance in a $\mathrm{NaCl}$ solution. Thermal welding treatment was used by Naderizadeh et al. [99] to achieve an exceedingly abrasion-resistant superhydrophobic silica nanoparticle-polymer coating on aluminum substrates. The process of etching lowers the surface energy of stainless steel in sulphuric acid to modify methyl trichlorosilane. Excellent anti-corrosive and self-cleaning properties have been exhibited by superhydrophobic stainless steel. The testing of the coating's wettability showed integrity in extreme bending, abrasion, and jet impact. There is increased susceptibility of cellulose paper to observe moisture from the developed wet and surroundings. Ogihara et al. [100] sprayed a deferral of hydrophobic silica nano-size particles onto hydrophilic paper to attain transparent and superhydrophobic silica nanoparticles on the hydrophilic paper.

Superhydrophobicity is likely to be exhibited by coating with silica nanoparticle suspension in ethanol because of ethanol hydrocarbon chain length. The wetting state of superhydrophobic paper is maintained after rolling, pressing, and folding. It is also possible to modify the nanoparticles of $\mathrm{SiO} 2, \mathrm{Al} 2 \mathrm{O} 3$, and $\mathrm{TiO} 2$ using a spray-coating on paper and silane coupling agents. Superhydrophobic behavior was revealed by paper coated with improved $\mathrm{SiO} 2$ nanoparticles, as it possesses the residual hydroxyl lowest amount groups; hydrocarbon groups easily replace these groups. Moreover, a transparent superhydrophobic coating was observed by Zhang et al. [101] via the wet deposition of an emulsion of carnauba wax and beeswax followed by annealing.

Continuous contact with water also results in wood degradation; therefore, a study by Jia et al. [102] was using a sol-gel process for preparing a durable superhydrophobic coating for use on wood surfaces. Good mechanical stability is likely to be demonstrated by applying vinyl improved silica nano-size particles on the wood using a simple solution immersion method against a sandpaper abrasion test. A study conducted by Wang et al. [103] cultivated $\mathrm{ZnO}$ nano-rods on a wood surface by fabricating a superhydrophobic wood surface with successive stearic acid modification. The hydrophobic silica suspension nano-size particles were used by Chang et al. [104] in a polydimethylsiloxane (PDMS) solution for coating wood surfaces.

Excellent superhydrophobicity is depicted by wood coated with SiO2-PDMS composites, along with decent mechanical durability against ultrasonic washing and abrasion. 
Another serious issue is oil spills in the environment, as superhydrophobic-superoleophobic sponges can provide efficient oil and water separation. A study conducted by Zhang et al. [105] it incorporated methyl-modified silica nano-size particles in porous PU matrix with the help of PDMS as an epoxy resin for fabricating superhydrophobic-superoleophobic polyurethane (PU) sponges. These sponges have an essential character in collecting oil from the water surface at high speed. Sponges have shown exceptional wetting stability touching alkali/acid immersion and abrasion. The sponges are modified for practical oilwater separation application with hydrophobic silica nanoparticles [106]. Previous studies have shown that the conservation of marbles, plastics, and frictional drag reduction is possible through superhydrophobic silica coatings [107]. The hydrophobic silica nanoparticle suspensions were coated on the various substrates. These substrates include a wall, solar cell panels, cotton shirt, paper, metal, marble, motorcycle's body, mini boat, window glass, fabric shoes, plastic, wood, and sponge.

\subsection{Materials Used in Superhydrophobic Coatings}

It is a core requirement that the surface must be rough at the nanoscale to make the surface hydrophobic. Techniques including deposition, self-assembly, lithography, and etching are used to prepare nanoparticles for superhydrophobic surfaces. Deposition methods encompass spin coating, spray coating, and dip coating, chemical vapour deposition, and sol-gel methodology [108-110]. These techniques can be categorized into two approaches: bottom-up and top-down. There is control of nanoscale structures in the bottom-up approach, whereas only the preferred nano/microstructures can be developed in the top-down approach. Lithography, micromachining, plasma treatment, etching, and templating are used to prepare superhydrophobic in a top-down approach. Material is added in a top-down approach onto the micro-or nanostructures and surface. This technique comprises the LBL approach, sol-gel method, and CVD [111].

Deposition took place due to a chemical reaction in a chamber in the CVD technique, where heated materials are present, and gases are flushed into the chamber, which is to be coated. This was completed in a cold-wall and hot-wall reactor, with or without carrier gases, at a temperature varying from $200^{\circ} \mathrm{C}$ to $1600^{\circ} \mathrm{C}$ [118]. Recently, several improved techniques have been created for CVD, including ion, plasma, laser, and photon, for increasing or decreasing the deposition rate. CVD's main benefit is that it can instill various materials and, along with that, high stability [112]. Trimethylmthoxysilane is also utilized for producing hydrophobic surfaces by PECVD.

Microelectronics-based photolithography is used in many universities and institutions for fabricating synthetic superhydrophobic surfaces. Bell Labs are likely to be used for manufacturing a photolithography-based array of silicon rods [113]. The hydrophobic solution is used to treat various one-micron diameter silicon rods to provide the right surface chemistry and microstructure for the rods to generate a static contact angle and a superhydrophobic surface of around $153^{\circ}$, as shown in Figure 16. 


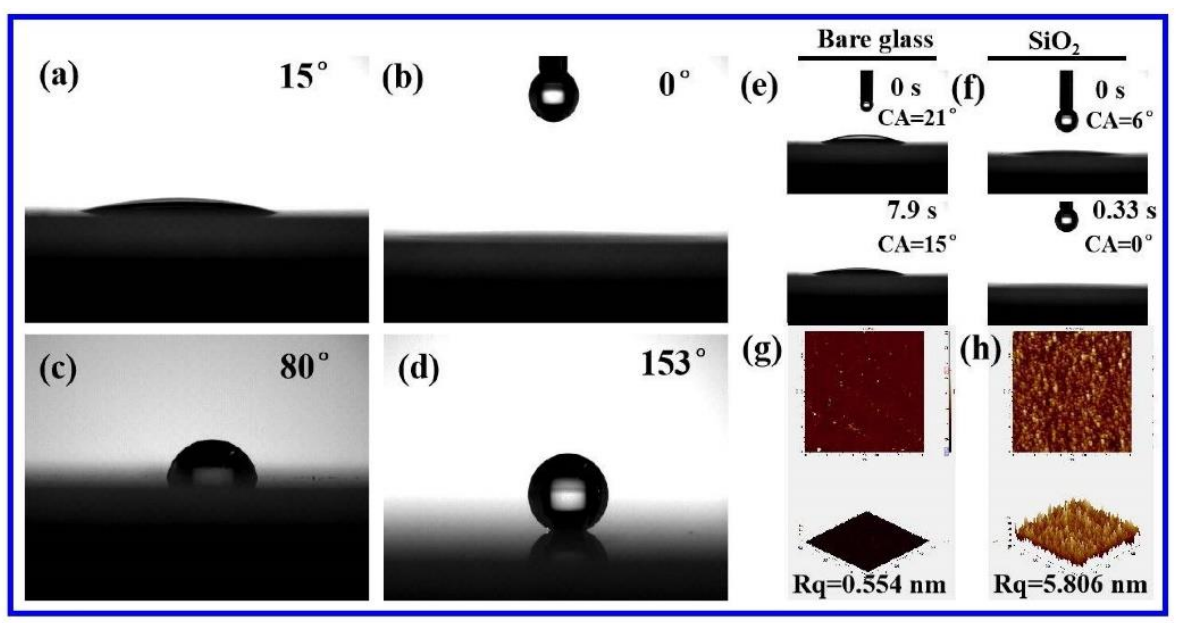

Figure 16. The images showed rods surface chemistry and microstructure generate a superhydrophobic surface and static contact angle of around $153^{\circ}$ [136].

Researchers at ORNL used glass fiber drawing techniques to make a glass cone spikes array in 2004. A seven microns periodicity and a height of 12 microns were possessed by the cones [114]. Handling the glass array with a fluorinated saline solution changed the glass cone array's surface chemistry to hydrophobic from hydrophilic. This solution offered covalent bonding on the surface of the cone. The radius of treated cone tips was $<10 \mathrm{~nm}$. The world's most water disgusting surface is provided by a superhydrophobic array of nano-sharp glass cones with a contact angle of $>179^{\circ}$ [115]. It has been shown that there are around one million cone spikes surrounded by water in monophony of a $14 \mathrm{~mm}$ diameter glass disc. Water seems to be repellently surrounding the $\mathrm{SH}$ cured cone array and the disc. This shows the disc surface no wetting. Borosilicate glass is separated by nano-porous silica and superhydrophobic nanostructured through a different etching phase [137].

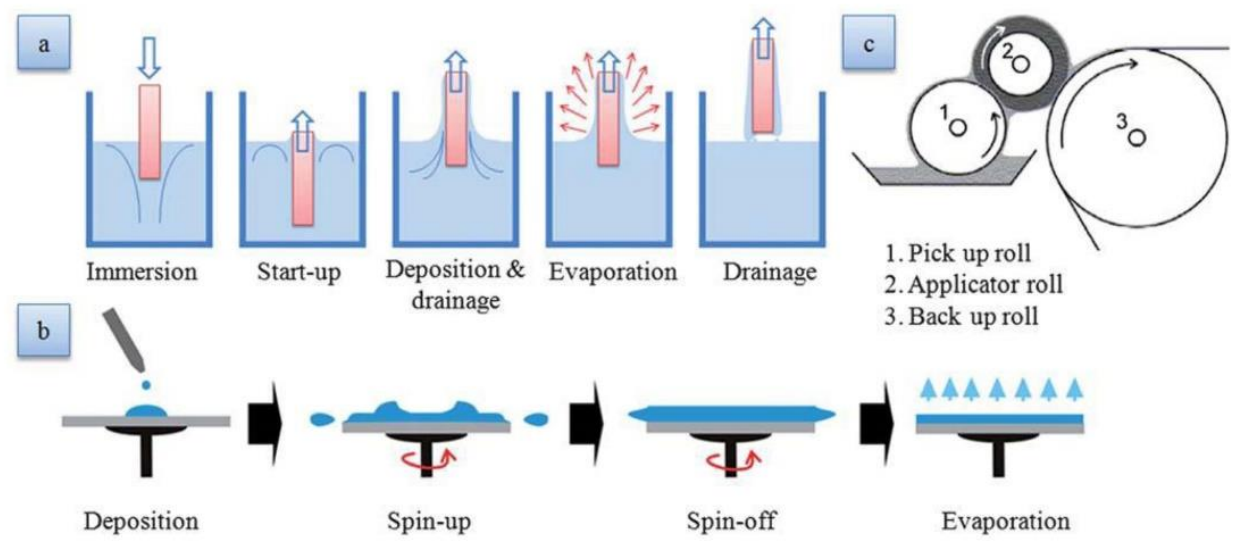

Figure 17. Demonstration of various techniques of meniscus coating [138].

In the decision, there are other physical and chemical methods presently being conducted for fabricating self-cleaning surfaces. Layer-by-layer, spin coating, and lithography are included in other solvent-based methods, whereas vacuum and thermal evaporation are amongst the gas phase coating strategies [139]. Nonetheless, these strategies rely on comparatively simple tools that could be enhanced to fabricate them more environ- 
mentally friendly. Besides, a specific method can be selected if the user is relying on specific applications, as exposed in Figure 17. The altered materials and methods utilized for anti-reflective, self-cleaning coatings are summarized in Table 2 below. Table 2 contains water contact angles, each coating's reflectance, and the light transmittance of materials.

Table 2. Methods and Materials used for Antireflective Self-cleaning Coatings Fabrication with Technical Details.

\begin{tabular}{|c|c|c|c|c|c|}
\hline Materials & $\begin{array}{l}\text { Water } \\
\text { Contact } \\
\text { Angles }\end{array}$ & $\begin{array}{c}\text { Transmittance } \\
(\%)\end{array}$ & Wavelength & $\begin{array}{c}\text { Reflectance } \\
(\%)\end{array}$ & Reference \\
\hline Silica sol & 108 & $99.63 \%$ & 529 & - & [116] \\
\hline $\mathrm{SiO}_{2}$ & 157 & $-95 \%$ & 580 & - & [117] \\
\hline $\begin{array}{l}\text { Mesoporous } \\
\text { silica nanopar- } \\
\text { ticles }\end{array}$ & - & - & 530 & & [119] \\
\hline $\mathrm{TiO} 2$ & 4.3 & $97.7 \%$ & 494 & - & [120] \\
\hline $\begin{array}{l}\text { Aluminum ox- } \\
\text { ide }\end{array}$ & - & - & 550 & $-2 \%$ & [121] \\
\hline $\begin{array}{l}\text { Aggregated } \\
\mathrm{SiO} 2 \text { particles }\end{array}$ & 165 & $92 \%$ & - & - & [122] \\
\hline Silica thin films & - & - & $567-573$ & $<1 \%$ & [123] \\
\hline SiO2 sol-gel & - & $99.2 \%$ & - & - & [124] \\
\hline $\mathrm{TiO} 2 / \mathrm{SiO} 2$ & - & - & $480-500$ & $0.15 \%$ & [125] \\
\hline $\begin{array}{l}\text { Scallion-like } \\
\mathrm{ZnO}\end{array}$ & 150 & - & $400-700$ & $<1 \%$ & [126] \\
\hline ITO & - & - & $350-450$ & UV-resistant & [127] \\
\hline $\begin{array}{l}\text { Reduced GO- } \\
\text { TiO2 }\end{array}$ & - & - & $540-560$ & $-10 \%$ & [128] \\
\hline $\mathrm{SiO} 2$ & - & $75 \%$ & - & - & [128] \\
\hline $\begin{array}{l}\text { Hollow Silica } \\
\text { nanoparticles }\end{array}$ & - & - & 520 & $-1 \%$ & [129] \\
\hline $\mathrm{Ag} / \mathrm{TiO} 2 / \mathrm{Si}$ & $<5$ & - & $300-650$ & $0.5 \%$ & [130] \\
\hline PVC template & - & - & $300-1000$ & $3.5 \%$ & [131] \\
\hline $\begin{array}{l}\text { Anodized alu- } \\
\text { minum oxide }\end{array}$ & 3 & - & 550 & $-5 \%$ & [132] \\
\hline Ag nano mask & - & - & - & $1.39 \%$ & [133] \\
\hline $\begin{array}{l}\text { AAO mem- } \\
\text { branes }\end{array}$ & - & - & $200-500$ & $<1 \%$ & [134] \\
\hline
\end{tabular}

\section{Conclusion}

In conclusion, solar cells' evolution has been reviewed established on a series of approaches and materials used all years. Solar cell materials range from crystalline silicon to the most advanced inorganic quantum dots. This study has shown how novel materials and techniques have facilitated researchers looking beyond silicon as an alternative solution to solar cell technology. The significance of using earth-abundant aspects in selecting active materials has been discussed for solar cells concerning reducing the cost/Watt of electricity. The need to use non-toxic elements in determining functional materials has 
also been discussed for accomplishing environmentally friendly and industrially viable solar cells for prospective events.

Photovoltaic technology is considered part of the solution for addressing energy concerns, and a fundamental aspect of upcoming energy production globally. In this paper, a detailed state description of the art research on photovoltaic cells has been founded. The altered methods and technologies proposed have been discussed comprehensively along with their characteristics, benefits, and challenges. In recent years, most first-generation and second-generation technologies have undergone several modifications involving highly standardized aspects. Moreover, while they portray high efficiency, they are usually expensive, even though there has been mitigation in the silicon-based cells costing.

On the contrary, most third generation and fourth-generation technologies are closely linked to the so-called fundamental research in this area. Laboratory prototypes have been developed, leading to better outcomes, even though they have not been integrated at an industrial level. Nonetheless, the third generation of multi-junction cells have been integrated commercially and have accomplished very high energy conversion rates. Fourth-generation cells comprise a potential field to be examined based on G, CNTs, or their derivatives in a state of initial research. The versatile nature of carbon nanostructure allows the implementation of PSC architecture, including the active layer, electrodes, and transport layers, to attain economically stable devices with enhanced performance.

\section{Future Recommendations}

Photovoltaic solar cells have not been made available on the market yet despite their progressively evident improvements in performance using carbon nanostructures. Therefore, there is a dire need to develop new approaches that facilitate the synthesis of highquality and G thin films or high-purity CNT with electronic properties and well-ordered morphology, as the bandgap, quality, and the carbon nanostructures morphology purity links back to the photovoltaic solar cell's performance.

Solution-processed films are needed with an optimum balance between sheet transparency and resistance. Besides, the ultrasonication and functionalization utilized throughout the fabrication of photovoltaic solar cells should become chief to a significant reduction in the carbon electrical conductivity nanomaterials. Therefore, the requirements of counter electrodes in photovoltaic solar cells cannot be fulfilled by the presence of the most conjugated polymer electrical properties of carbon nanotube composites.

Novel synthetic methods are needed for the prevention of aggregation. Novel functionalization or doping approaches compatible with photovoltaic solar panel fabrication procedures need to be devised to attain higher stability, tunable energy levels, and enhanced charge transport in carbon-based nanomaterials. Furthermore, new economic techniques that facilitate the synthesis of G and CNTs are required on a large scale; their low yields seriously confine existing methods, which should be addressed before their commercial applications.

Acknowledgments: The author would like to thank the Deanship of Scientific Research at Majmaah University for supporting this work under project number xxxx-xx.

Conflicts of Interest: The author declares no conflict of interest.

\section{References}

1. Diouf, B.; Pode, R. Potential of lithium-ion batteries in renewable energy. Renew. Energy 2015, 7.

2. Banger R. Electricity Generation from PV TR Cells at Day and Nighttime from Space Energy. Juni Khyat UGC Care J. 2020, 10.

3. Gavrik, A.; Mannanov, A.L.; Tsarev, S.; Bruevich, V. V.; Trukhanov, V.A.; Chernikov, Y.A.; Savchenko, P.S.; Gvozdkova, J.D.; Solodukhin, A.N.; Troshin, P.A.; et al. Spectral technique for accurate efficiency measurements of emerging solar cells. Sol. Energy 2020, 206, doi:10.1016/j.solener.2020.06.015.

4. Barman, B.; Kalita, P.K. Influence of back surface field layer on enhancing the efficiency of CIGS solar cell. Sol. Energy 2021, 216, 329-337, doi:10.1016/j.solener.2021.01.032. 
5. Hu, A.; Zhou, J.; Qin, X.; Jiang, Y.; Zhou, P.; Zhong, P.; Tang, S.; Wu, X.; Yang, D. Improving CdTe-Based Thin-Film Solar Cell Efficiency with the Oxygenated CdSe Layer Prepared by Sputtering Process. Phys. Status Solidi Appl. Mater. Sci. 2020, 217, doi:10.1002/pssa.202000560.

6. Jiang, J.; Lv, Q.; Gao, X. The ultra-short-term forecasting of global horizonal irradiance based on total sky images. Remote Sens. 2020, 12, doi:10.3390/rs12213671.

7. Verlinden, P.J. Future challenges for photovoltaic manufacturing at the terawatt level. J. Renew. Sustain. Energy 2020, 12, doi:10.1063/5.0020380.

8. Sonntag, P.; Preissler, N.; Bokalič, M.; Trahms, M.; Haschke, J.; Schlatmann, R.; Topič, M.; Rech, B.; Amkreutz, D. Silicon solar cells on glass with power conversion efficiency above $13 \%$ at thickness below 15 micrometers. Sci. Rep. 2017, 7.

9. Jäger, K.; Isabella, O.; Smets, A.H.M.; Swaaij, R.A.C.M.M. van; Zeman, M. Solar energy: Fundamentals, Technology, and Systems; 2014.

10. Sharma, S.; Jain, K.K.; Sharma, A. Solar Cells: In Research and Applications-A Review. Mater. Sci. Appl. 2015, 06, doi:10.4236.

11. Chander, S.; Purohit, A.; Sharma, A.; Arvind; Nehra, S.P.; Dhaka, M.S. A study on photovoltaic parameters of mono-crystalline silicon solar cell with cell temperature. Energy Reports 2015, 1.

12. Baker-Finch, S.C.; McIntosh, K.R. Reflection distributions of textured monocrystalline silicon: Implications for silicon solar cells. Prog. Photovoltaics Res. Appl. 2013, 21.

13. Squeo, B.M.; Ganzer, L.; Virgili, T.; Pasini, M. BODIPY-Based Molecules, a Platform for Photonic and Solar Cells. Molecules $2020,26$.

14. Van Gestel, D.; Gordon, I.; Poortmans, J. Aluminum-induced crystallization for thin-film polycrystalline silicon solar cells: Achievements and perspective. Sol. Energy Mater. Sol. Cells 2013, 119, doi:10.1016/j.solmat.2013.08.014.

15. Becker, C.; Amkreutz, D.; Sontheimer, T.; Preidel, V.; Lockau, D.; Haschke, J.; Jogschies, L.; Klimm, C.; Merkel, J.J.; Plocica, P.; et al. Polycrystalline silicon thin-film solar cells: Status and perspectives. Sol. Energy Mater. Sol. Cells 2013, 119, doi:10.1016/j.solmat.2013.05.043.

16. Zargar, M.; Hamid, A.A.; Bakar, F.A.; Shamsudin, M.N.; Shameli, K.; Jahanshiri, F.; Farahani, F. Green synthesis and antibacterial effect of silver nanoparticles using Vitex negundo L. Molecules 2011, 16, doi:10.3390/molecules16086667.

17. Minbashi, M.; Ghobadi, A.; Ehsani, M.H.; Rezagholipour Dizaji, H.; Memarian, N. Simulation of high efficiency SnS-based solar cells with SCAPS. Sol. Energy 2018, 176, doi:10.1016/j.solener.2018.10.058.

18. Tseng, F.M.; Hsieh, C.H.; Peng, Y.N.; Chu, Y.W. Using patent data to analyze trends and the technological strategies of the amorphous silicon thin-film solar cell industry. Technol. Forecast. Soc. Change 2011, 78, doi:10.1016/j.techfore.2010.10.010.

19. Meng, X.; Gomard, G.; El Daif, O.; Drouard, E.; Orobtchouk, R.; Kaminski, A.; Fave, A.; Lemiti, M.; Abramov, A.; Roca I Cabarrocas, P.; et al. Absorbing photonic crystals for silicon thin-film solar cells: Design, fabrication, and experimental investigation. In Proceedings of the Solar Energy Materials and Solar Cells; 2011; Vol. 95.

20. Badawy, W.A. A review on solar cells from Si-single crystals to porous materials and Quantum dots. J. Adv. Res. 2015, 6.

21. Palanchoke, U.; Jovanov, V.; Kurz, H.; Obermeyer, P.; Stiebig, H.; Knipp, D. Plasmonic effects in amorphous silicon thin film solar cells with metal back contacts. Opt. Express 2012, 20, doi:10.1364/oe.20.006340.

22. Jovanov, V.; Xu, X.; Shrestha, S.; Schulte, M.; Hüpkes, J.; Zeman, M.; Knipp, D. Influence of interface morphologies on amorphous silicon thin film solar cells prepared on randomly textured substrates. Sol. Energy Mater. Sol. Cells 2013, 112, doi:10.1016/j.solmat.2013.01.017.

23. Wang, F.H.; Chang, H.P.; Tseng, C.C.; Huang, C.C.; Liu, H.W. Influence of hydrogen plasma treatment on Al-doped ZnO thin films for amorphous silicon thin film solar cells. In Proceedings of the Current Applied Physics; 2011; Vol. 11.

24. Gomard, G.; Drouard, E.; Letartre, X.; Meng, X.; Kaminski, A.; Fave, A.; Lemiti, M.; Garcia-Caurel, E.; Seassal, C. Twodimensional photonic crystal for absorption enhancement in hydrogenated amorphous silicon thin film solar cells. J. Appl. Phys. 2010, 108, doi:10.1063/1.3506702.

25. Kang, D.W.; Ryu, J.; Konagai, M. High-Performance Amorphous Silicon Thin Film Solar Cells Prepared at $100{ }^{\circ} \mathrm{C}$ : Toward Flexible Building-Integrated Photovoltaics. Electron. Mater. Lett. 2019, 15, doi:10.1007/s13391-019-00161-8.

26. Bertini, S.; Risi, G.; Guerrini, M.; Carrick, K.; Szajek, A.Y.; Mulloy, B. Molecular Weights of Bovine and Porcine Heparin Samples: Comparison of Chromatographic Methods and Results of a Collaborative Survey. Molecules 2017, 22, doi:10.3390/molecules22071214.

27. Castillo, A.; Gayme, D.F. Grid-scale energy storage applications in renewable energy integration: A survey. Energy Convers. Manag. 2014, 87.

28. Liu, S.; Yi, S.; Qing, P.; Li, W.; Gu, B.; He, Z.; Zhang, B. Molecular engineering enhances the charge carriers transport in wide band-gap polymer donors-based polymer solar cells. Molecules 2020, 25, doi:10.3390/molecules25184101.

29. Elsabawy, K.M.; El-Hawary, W.F.; Refat, M.S. Advanced synthesis of titanium-dopedtellerium-cadmium mixtures for high performance solar cell applications as one of renewable source of energy. Int. J. Chem. Sci. 2012, 10.

30. Ndiaye, A.; Dioum, A.; Oprea, C.I.; Dumbrava, A.; Lungu, J.; Georgescu, A.; Moscalu, F.; Gîrţu, M.A.; Beye, A.C.; Youm, I. A Combined Experimental and Computational Study of Chrysanthemin as a Pigment for Dye-Sensitized Solar Cells. Molecules 2021, 26, doi:10.3390/molecules26010225. 
31. Sethi, V.K.; Pandey, M.; Shukla, P. Use of Nanotechnology in Solar PV Cell. Int. J. Chem. Eng. Appl. 2011, doi:10.7763/ijcea.2011.v2.79.

32. Ishizuka, S.; Koida, T.; Taguchi, N.; Tanaka, S.; Fons, P.; Shibata, H. Si-Doping Effects in Cu(In,Ga)Se2 Thin Films and Applications for Simplified Structure High-Efficiency Solar Cells. ACS Appl. Mater. Interfaces 2017, 9, doi:10.1021/acsami.7b09019.

33. Razykov, T.M.; Ferekides, C.S.; Morel, D.; Stefanakos, E.; Ullal, H.S.; Upadhyaya, H.M. Solar photovoltaic electricity: Current status and future prospects. Sol. Energy 2011, 85, doi:10.1016/j.solener.2010.12.002.

34. Zhang, N.; Luo, M.; He, L.; Yao, L. Chemical composition of essential oil from flower of $\nabla$ shanzhizi $\Leftrightarrow$ (gardenia jasminoides ellis) and involvement of serotonergic system in its anxiolytic effect. Molecules 2020, 25, doi:10.3390/molecules25204702.

35. Choubey, P.C.; Oudhia, A.; Dewangan, R.; Autonomous, V.Y.T.P.G. A review : Solar cell current scenario and future trends. Recent Res. Sci. Technol. 2012 2012, 4.

36. Dubey, S.; Sarvaiya, J.N.; Seshadri, B. Temperature dependent photovoltaic (PV) efficiency and its effect on PV production in the world - A review. In Proceedings of the Energy Procedia; 2013; Vol. 33.

37. Lunt, R.R.; Bulovic, V. Transparent, near-infrared organic photovoltaic solar cells for window and energy-scavenging applications. Appl. Phys. Lett. 2011, 98, doi:10.1063/1.3567516.

38. Lunt, R.R.; Osedach, T.P.; Brown, P.R.; Rowehl, J.A.; Bulović, V. Practical roadmap and limits to nanostructured photovoltaics. Adv. Mater. 2011, 23, doi:10.1002/adma.201103404.

39. Lunt, R.R. Theoretical limits for visibly transparent photovoltaics. Appl. Phys. Lett. 2012, 101, doi:10.1063/1.4738896.

40. Zhu, R.; Kumar, A.; Yang, Y. Polarizing organic photovoltaics. Adv. Mater. 2011, 23, doi:10.1002/adma.201101514.

41. Suhaimi, S.; Shahimin, M.M.; Alahmed, Z.A.; Chyský, J.; Reshak, A.H. Materials for enhanced dye-sensitized solar cell performance: Electrochemical application. Int. J. Electrochem. Sci. 2015, 10.

42. Graetzel, M.; Janssen, R.A.J.; Mitzi, D.B.; Sargent, E.H. Materials interface engineering for solution-processed photovoltaics. Nature 2012, 488.

43. Nozik, A.J. Nanoscience and nanostructures for photovoltaics and solar fuels. Nano Lett. 2010, 10, doi:10.1021/nl102122x.

44. Jun, M.C.; Park, S.U.; Koh, J.H. Comparative studies of Al-doped ZnO and Gadoped ZnO transparent conducting oxide thin films. Nanoscale Res. Lett. 2012, 7, doi:10.1186/1556-276X-7-639.

45. Ye, S.; Rao, H.; Yan, W.; Li, Y.; Sun, W.; Peng, H.; Liu, Z.; Bian, Z.; Li, Y.; Huang, C. A Strategy to Simplify the Preparation Process of Perovskite Solar Cells by Co-deposition of a Hole-Conductor and a Perovskite Layer. Adv. Mater. 2016, 28, doi:10.1002/adma.201603850.

46. Wu, Y.; Wan, L.; Fu, S.; Zhang, W.; Li, X.; Fang, J. Liquid metal acetate assisted preparation of high-efficiency and stable inverted perovskite solar cells. J. Mater. Chem. A 2019, 7, doi:10.1039/c9ta04192c.

47. Nakade, S.; Matsuda, M.; Kambe, S.; Saito, Y.; Kitamura, T.; Sakata, T.; Wada, Y.; Mori, H.; Yanagida, S. Dependence of TiO2 nanoparticle preparation methods and annealing temperature on the efficiency of dye-sensitized solar cells. J. Phys. Chem. B 2002, 106, doi:10.1021/jp020051d.

48. Saunders, B.R. Hybrid polymer/nanoparticle solar cells: Preparation, principles and challenges. J. Colloid Interface Sci. 2012, 369, doi:10.1016/j.jcis.2011.12.016.

49. Saha, S.K. Materials Research and Opportunities in Solar (Photovoltaic) Cells. Proc. Indian Natl. Sci. Acad. 2015, 81, doi:10.16943/ptinsa/2015/v81i4/48309.

50. Kaelin, M.; Rudmann, D.; Tiwari, A.N. Low-cost processing of CIGS thin film solar cells. Sol. Energy 2004, 77, doi:10.1016/j.solener.2004.08.015.

51. Wuerz, R.; Eicke, A.; Frankenfeld, M.; Kessler, F.; Powalla, M.; Rogin, P.; Yazdani-Assl, O. CIGS thin-film solar cells on steel substrates. Thin Solid Films 2009, 517, doi:10.1016/j.tsf.2008.11.016.

52. Kaelin, M.; Rudmann, D.; Kurdesau, F.; Zogg, H.; Meyer, T.; Tiwari, A.N. Low-cost CIGS solar cells by paste coating and selenization. In Proceedings of the Thin Solid Films; 2005; Vol. 480-481.

53. Lundberg, O.; Edoff, M.; Stolt, L. The effect of Ga-grading in CIGS thin film solar cells. In Proceedings of the Thin Solid Films; 2005; Vol. 480-481.

54. Saji, V.S.; Choi, I.H.; Lee, C.W. Progress in electrodeposited absorber layer for CuIn(1-x)GaxSe2 (CIGS) solar cells. Sol. Energy 2011, 85, doi:10.1016/j.solener.2011.08.003.

55. Cui, J.; Meng, F.; Zhang, H.; Cao, K.; Yuan, H.; Cheng, Y.; Huang, F.; Wang, M. CH3NH3PbI3-based planar solar cells with magnetron-sputtered nickel oxide. ACS Appl. Mater. Interfaces 2014, 6, doi:10.1021/am507108u.

56. Scragg, J.J.; Ericson, T.; Fontané, X.; Izquierdo-Roca, V.; Pérez-Rodríguez, A.; Kubart, T.; Edoff, M.; Platzer-Björkman, C. Rapid annealing of reactively sputtered precursors for $\mathrm{Cu} 2 \mathrm{ZnSnS4}$ solar cells. Prog. Photovoltaics Res. Appl. 2014, 22, doi:10.1002/pip.2265.

57. Fernandes, P.A.; Salomé, P.M.P.; Da Cunha, A.F.; Schubert, B.A. Cu2ZnSnS4 solar cells prepared with sulphurized dc-sputtered stacked metallic precursors. In Proceedings of the Thin Solid Films; 2011; Vol. 519.

58. Li, G.; Jiang, Y.; Deng, S.; Tam, A.; Xu, P.; Wong, M.; Kwok, H.S. Overcoming the Limitations of Sputtered Nickel Oxide for High-Efficiency and Large-Area Perovskite Solar Cells. Adv. Sci. 2017, 4, doi:10.1002/advs.201700463. 
59. Yin Vallgren, C.; Ashraf, A.; Calatroni, S.; Chiggiato, P.; Costa Pinto, P.; Marques, H.P.; Neupert, H.; Taborelli, M.; Vollenberg, W.; Wevers, I.; et al. Low secondary electron yield carbon coatings for electron cloud mitigation in modern particle accelerators. In Proceedings of the IPAC 2010 - 1st International Particle Accelerator Conference; 2010.

60. Kim, J.; Park, C.; Pawar, S.M.; Inamdar, A.I.; Jo, Y.; Han, J.; Hong, J.; Park, Y.S.; Kim, D.Y.; Jung, W.; et al. Optimization of sputtered ZnS buffer for Cu2ZnSnS4 thin film solar cells. Thin Solid Films 2014, 566, doi:10.1016/j.tsf.2014.07.024.

61. Ericson, T.; Kubart, T.; Scragg, J.J.; Platzer-Björkman, C. Reactive sputtering of precursors for Cu 2ZnSnS 4 thin film solar cells. Thin Solid Films 2012, 520, doi:10.1016/j.tsf.2012.08.002.

62. Han, L.; Islam, A.; Chen, H.; Malapaka, C.; Chiranjeevi, B.; Zhang, S.; Yang, X.; Yanagida, M. High-efficiency dye-sensitized solar cell with a novel co-adsorbent. Energy Environ. Sci. 2012, 5, doi:10.1039/c2ee03418b.

63. Chen, X.; Tang, Y.; Liu, W. efficient dye-sensitized solar cells based on nanoflower-like ZnO photoelectrode. Molecules 2017, 22, doi:10.3390/molecules22081284.

64. Nazeeruddin, M.K.; Baranoff, E.; Grätzel, M. Dye-sensitized solar cells: A brief overview. Sol. Energy 2011, 85, doi:10.1016/j.solener.2011.01.018.

65. Richhariya, G.; Kumar, A.; Tekasakul, P.; Gupta, B. Natural dyes for dye sensitized solar cell: A review. Renew. Sustain. Energy Rev. 2017, 69.

66. Deng, Y.; Peng, E.; Shao, Y.; Xiao, Z.; Dong, Q.; Huang, J. Scalable fabrication of efficient organolead trihalide perovskite solar cells with doctor-bladed active layers. Energy Environ. Sci. 2015, 8, doi:10.1039/c4ee03907f.

67. Azizi, T.; Touihri, A.E.; Ben Karoui, M.; Gharbi, R. Comparative study between dye-synthesized solar cells prepared by electrophoretic and doctor blade techniques. Optik (Stuttg). 2016, 127, doi:10.1016/j.ijleo.2016.01.191.

68. Nang Dinh, N.; Minh Quyen, N.; Chung, D.N.; Zikova, M.; Truong, V. Van Highly-efficient electrochromic performance of nanostructured TiO 2 films made by doctor blade technique. Sol. Energy Mater. Sol. Cells 2011, 95, doi:10.1016/j.solmat.2010.09.028.

69. Basak, A.; Deka, H.; Mondal, A.; Singh, U.P. Impact of post-deposition annealing in Cu2SnS3 thin film solar cells prepared by doctor blade method. Vacuum 2018, 156, doi:10.1016/j.vacuum.2018.07.049.

70. Huynh, T.P.; Hoanq, T.T.; Nguyen, P.H.; Tran, T.N.; Nguyen, T.V. Preparation of TiO2 thin film using modified doctorblade method for improvement of dye-sensitized solar cell. In Proceedings of the Conference Record of the IEEE Photovoltaic Specialists Conference; 2009.

71. Pi, X.; Li, Q.; Li, D.; Yang, D. Spin-coating silicon-quantum-dot ink to improve solar cell efficiency. Sol. Energy Mater. Sol. Cells 2011, 95, doi:10.1016/j.solmat.2011.06.010.

72. Carlé, J.E.; Andersen, T.R.; Helgesen, M.; Bundgaard, E.; Jorgensen, M.; Krebs, F.C. A laboratory scale approach to polymer solar cells using one coating/printing machine, flexible substrates, no ITO, no vacuum and no spincoating. In Proceedings of the Solar Energy Materials and Solar Cells; 2013; Vol. 108.

73. Swami, S.K.; Kumar, A.; Dutta, V. Deposition of kesterite Cu2ZnSnS4 (CZTS) thin films by spin coating technique for solar cell application. In Proceedings of the Energy Procedia; 2013; Vol. 33.

74. Todorov, T.K.; Singh, S.; Bishop, D.M.; Gunawan, O.; Lee, Y.S.; Gershon, T.S.; Brew, K.W.; Antunez, P.D.; Haight, R. Ultrathin high band gap solar cells with improved efficiencies from the world's oldest photovoltaic material. Nat. Commun. 2017, 8, doi:10.1038/s41467-017-00582-9.

75. Green, M.A.; Dunlop, E.D.; Levi, D.H.; Hohl-Ebinger, J.; Yoshita, M.; Ho-Baillie, A.W.Y. Solar cell efficiency tables (version 54). Prog. Photovoltaics Res. Appl. 2019, 27, doi:10.1002/pip.3171.

76. Jin, R.; Zhang, X.; Xiao, W. Theoretical studies of photophysical properties of $\mathrm{d}-\pi-\mathrm{a}-\pi-\mathrm{D}$-type diketopyrrolopyrrole-based molecules for organic light-emitting diodes and organic solar cells. Molecules 2020, 25, doi:10.3390/molecules25030667.

77. Werner, J.; Weng, C.H.; Walter, A.; Fesquet, L.; Seif, J.P.; De Wolf, S.; Niesen, B.; Ballif, C. Efficient Monolithic Perovskite/Silicon Tandem Solar Cell with Cell Area $>1$ cm2. J. Phys. Chem. Lett. 2016, 7, doi:10.1021/acs.jpclett.5b02686.

78. Luo, S.; Daoud, W.A. Recent progress in organic-inorganic halide perovskite solar cells: Mechanisms and material design. J. Mater. Chem. A 2015, 3, doi:10.1039/c4ta04953e.

79. Ma, J.; Guo, D. A data review on certified perovskite solar cells efficiency and I-V metrics: Insights into materials selection and process scaling up. Sol. Energy 2020, 209.

80. Ma, J.; Guo, D. A data review on certified perovskite solar cells efficiency and I-V metrics: Insights into materials selection and process scaling up.

81. McMullin, B.J. Bibliographical Query: The Suttontype Printing Process. Scr. Print 2011, 35.

82. Sharma, V.; Chandel, S.S. A novel study for determining early life degradation of multi-crystalline-silicon photovoltaic modules observed in western Himalayan Indian climatic conditions. Sol. Energy 2016, 134, doi:10.1016/j.solener.2016.04.023.

83. Green, M.A. Erratum: Solar cell efficiency tables (version 46) (Progress in Photovoltaics: Research and Applications (2015) 23 (805-812)). Prog. Photovoltaics Res. Appl. 2015, 23.

84. Kahn, J.M.; Miller, D.A.B. Communications expands its space. Nat. Photonics 2017, 11, doi:10.1038/nphoton.2016.256.

85. Green, M.A. Silicon solar cells: State of the art. Philos. Trans. R. Soc. A Math. Phys. Eng. Sci. 2013, 371.

86. Todorov, T.; Gershon, T.; Gunawan, O.; Lee, Y.S.; Sturdevant, C.; Chang, L.Y.; Guha, S. Monolithic Perovskite-CIGS Tandem Solar Cells via in Situ Band Gap Engineering. Adv. Energy Mater. 2015, 5, doi:10.1002/aenm.201500799. 
87. Kim, B.S.; Kim, T.M.; Choi, M.S.; Shim, H.S.; Kim, J.J. Fully vacuum-processed perovskite solar cells with high open circuit voltage using MoO3/NPB as hole extraction layers. Org. Electron. 2015, 17, doi:10.1016/j.orgel.2014.12.002.

88. Luo, J.; Li, Z.; Nishiwaki, S.; Schreier, M.; Mayer, M.T.; Cendula, P.; Lee, Y.H.; Fu, K.; Cao, A.; Nazeeruddin, M.K.; et al. Targeting Ideal Dual-Absorber Tandem Water Splitting Using Perovskite Photovoltaics and CuInxGa1-xSe2 Photocathodes. Adv. Energy Mater. 2015, 5, doi:10.1002/aenm.201501520.

89. Na, S.I.; Seo, Y.H.; Nah, Y.C.; Kim, S.S.; Heo, H.; Kim, J.E.; Rolston, N.; Dauskardt, R.H.; Gao, M.; Lee, Y.; et al. High Performance Roll-to-Roll Produced Fullerene-Free Organic Photovoltaic Devices via Temperature-Controlled Slot Die Coating. Adv. Funct. Mater. 2019, 29, doi:10.1002/adfm.201805825.

90. Pichumani, M.; Bagheri, P.; Poduska, K.M.; González-Viñas, W.; Yethiraj, A. Dynamics, crystallization and structures in colloid spin coating. Soft Matter 2013, 9.

91. Bayer, I.S. On the durability and wear resistance of transparent superhydrophobic coatings. Coatings $2017,7$.

92. Milionis, A.; Sharma, C.S.; Hopf, R.; Uggowitzer, M.; Bayer, I.S.; Poulikakos, D. Engineering Fully Organic and Biodegradable Superhydrophobic Materials. Adv. Mater. Interfaces 2019, 6, doi:10.1002/admi.201801202.

93. Lai, Y.; Huang, J.; Cui, Z.; Ge, M.; Zhang, K.Q.; Chen, Z.; Chi, L. Recent Advances in TiO2-Based Nanostructured Surfaces with Controllable Wettability and Adhesion. Small 2016, 12, doi:10.1002/smll.201501837.

94. Xu, L.; He, J. Fabrication of highly transparent superhydrophobic coatings from hollow silica nanoparticles. Langmuir 2012, 28, doi:10.1021/la301420p.

95. Liu, S.; Liu, X.; Latthe, S.S.; Gao, L.; An, S.; Yoon, S.S.; Liu, B.; Xing, R. Self-cleaning transparent superhydrophobic coatings through simple sol-gel processing of fluoroalkylsilane. Appl. Surf. Sci. 2015, 351, doi:10.1016/j.apsusc.2015.06.016.

96. Xu, L.; Karunakaran, R.G.; Guo, J.; Yang, S. Transparent, superhydrophobic surfaces from one-step spin coating of hydrophobic nanoparticles. ACS Appl. Mater. Interfaces 2012, 4, doi:10.1021/am201750h.

97. Gao, Q.; Zhu, Q.; Guo, Y.; Yang, C.Q. Formation of highly hydrophobic surfaces on cotton and polyester fabrics using silica sol nanoparticles and nonfluorinated alkylsilane. Ind. Eng. Chem. Res. 2009, 48, doi:10.1021/ie9005518.

98. Xue, C.H.; Jia, S.T.; Chen, H.Z.; Wang, M. Superhydrophobic cotton fabrics prepared by sol-gel coating of TiO 2 and surface hydrophobization. Sci. Technol. Adv. Mater. 2008, 9, doi:10.1088/1468-6996/9/3/035001.

99. Wu, L.K.; Zhang, X.F.; Hu, J.M. Corrosion protection of mild steel by one-step electrodeposition of superhydrophobic silica film. Corros. Sci. 2014, 85, doi:10.1016/j.corsci.2014.04.026.

100. Naderizadeh, S.; Athanassiou, A.; Bayer, I.S. Interfacing superhydrophobic silica nanoparticle films with graphene and thermoplastic polyurethane for wear/abrasion resistance. J. Colloid Interface Sci. 2018, 519, doi:10.1016/j.jcis.2018.02.065.

101. Ogihara, H.; Xie, J.; Okagaki, J.; Saji, T. Simple method for preparing superhydrophobic paper: Spray-deposited hydrophobic silica nanoparticle coatings exhibit high water-repellency and transparency. Langmuir 2012, 28, doi:10.1021/la204492q.

102. Zhang, W.; Lu, P.; Qian, L.; Xiao, H. Fabrication of superhydrophobic paper surface via wax mixture coating. Chem. Eng. J. 2014, 250, doi:10.1016/j.cej.2014.04.050.

103. Jia, S.; Chen, H.; Luo, S.; Qing, Y.; Deng, S.; Yan, N.; Wu, Y. One-step approach to prepare superhydrophobic wood with enhanced mechanical and chemical durability: Driving of alkali. Appl. Surf. Sci. 2018, 455, doi:10.1016/j.apsusc.2018.05.169.

104. Wang, C.; Piao, C.; Lucas, C. Synthesis and characterization of superhydrophobic wood surfaces. J. Appl. Polym. Sci. 2011, 119, doi:10.1002/app.32844.

105. Chang, H.; Tu, K.; Wang, X.; Liu, J. Fabrication of mechanically durable superhydrophobic wood surfaces using polydimethylsiloxane and silica nanoparticles. RSC Adv. 2015, 5, doi:10.1039/c5ra03070f.

106. Zhang, X.; Zhi, D.; Zhu, W.; Sathasivam, S.; Parkin, I.P. Facile fabrication of durable superhydrophobic SiO2/polyurethane composite sponge for continuous separation of oil from water. RSC Adv. 2017, 7, doi:10.1039/c7ra00020k.

107. Cui, W.; Pakkanen, T.A. Icephobic performance of one-step silicone-oil-infused slippery coatings: Effects of surface energy, oil and nanoparticle contents. J. Colloid Interface Sci. 2019, 558, doi:10.1016/j.jcis.2019.09.119.

108. Aslanidou, D.; Karapanagiotis, I.; Lampakis, D. Waterborne superhydrophobic and superoleophobic coatings for the protection of marble and sandstone. Materials (Basel). 2018, 11, doi:10.3390/ma11040585.

109. Bhushan, B.; Jung, Y.C. Natural and biomimetic artificial surfaces for superhydrophobicity, self-cleaning, low adhesion, and drag reduction. Prog. Mater. Sci. 2011, 56.

110. Mohamed, A.M.A.; Abdullah, A.M.; Younan, N.A. Corrosion behavior of superhydrophobic surfaces: A review. Arab. J. Chem. 2015, 8 .

111. Shalaby, A.; Dimitriev, Y.; Iordanova, R.; Bachvarova-Nedelcheva, A.; Iliev, T. Modified sol-gel synthesis of submicron powders in the system ZnO-TiO2. J. Univ. Chem. Technol. Metall. 2011, 46.

112. Jeevahan, J.; Chandrasekaran, M.; Britto Joseph, G.; Durairaj, R.B.; Mageshwaran, G. Superhydrophobic surfaces: a review on fundamentals, applications, and challenges. J. Coatings Technol. Res. 2018, 15.

113. Martin, P.M. Introduction to Surface Engineering and Functionally Engineered Materials; 2011;

114. Simpson, J.T.; Hunter, S.R.; Aytug, T. Superhydrophobic materials and coatings: A review. Reports Prog. Phys. $2015,78$.

115. D'Urso, B.; Simpson, J.T.; Kalyanaraman, M. Emergence of superhydrophobic behavior on vertically aligned nanocone arrays. Appl. Phys. Lett. 2007, 90, doi:10.1063/1.2433039. 
116. Zhang, X.; Shi, F.; Niu, J.; Jiang, Y.; Wang, Z. Superhydrophobic surfaces: From structural control to functional application. J. Mater. Chem. 2008, 18, doi:10.1039/b711226b.

117. Cai, S.; Zhang, Y.; Zhang, H.; Yan, H.; Lv, H.; Jiang, B. Sol-gel preparation of hydrophobic silica antireflective coatings with low refractive index by base/acid two-step catalysis. ACS Appl. Mater. Interfaces 2014, 6, doi:10.1021/am501972y.

118. Wu, Z.; Caliot, C.; Flamant, G.; Wang, Z. Coupled radiation and flow modeling in ceramic foam volumetric solar air receivers. Sol. Energy 2011, 85, doi:10.1016/j.solener.2011.06.030.

119. Li, Y.; Liu, F.; Sun, J. A facile layer-by-layer deposition process for the fabrication of highly transparent superhydrophobic coatings. Chem. Commun. 2009, doi:10.1039/b900804g.

120. Zhang, X.T.; Sato, O.; Taguchi, M.; Einaga, Y.; Murakami, T.; Fujishima, A. Self-cleaning particle coating with antireflection properties. Chem. Mater. 2005, 17, doi:10.1021/cm0484201.

121. Du, X.; Xing, Y.; Zhou, M.; Li, X.; Huang, H.; Meng, X.M.; Wen, Y.; Zhang, X. Broadband antireflective superhydrophilic antifogging nano-coatings based on three-layer system. Microporous Mesoporous Mater. 2018, 255, doi:10.1016/j.micromeso.2017.07.017.

122. Selhofer, H.; Ritter, E.; Linsbod, R. Properties of titanium dioxide films prepared by reactive electron-beam evaporation from various starting materials. Appl. Opt. 2002, 41, doi:10.1364/AO.41.000756.

123. Tadanaga, K.; Katata, N.; Minami, T. Super-water-repellent Al2O3 coating films with high transparency. J. Am. Ceram. Soc. 1997, 80, doi:10.1111/j.1151-2916.1997.tb02943.x.

124. Cook, K.T.; Tettey, K.E.; Bunch, R.M.; Lee, D.; Nolte, A.J. One-step index-tunable antireflection coatings from aggregated silica nanoparticles. ACS Appl. Mater. Interfaces 2012, 4, doi:10.1021/am3020586.

125. Xu, L.; He, J. A novel precursor-derived one-step growth approach to fabrication of highly antireflective, mechanically robust and self-healing nanoporous silica thin films. J. Mater. Chem. C 2013, 1, doi:10.1039/c3tc30734d.

126. Prado, R.; Beobide, G.; Marcaide, A.; Goikoetxea, J.; Aranzabe, A. Development of multifunctional sol-gel coatings: Antireflection coatings with enhanced self-cleaning capacity. Sol. Energy Mater. Sol. Cells 2010, 94, doi:10.1016/j.solmat.2010.02.031.

127. Lee, D.; Gemici, Z.; Rubner, M.F.; Cohen, R.E. Multilayers of oppositely charged SiO2 nanoparticles: Effect of surface charge on multilayer assembly. Langmuir 2007, 23, doi:10.1021/la701267a.

128. Wu, Y.; Chen, C.; Liu, Y.; Xu, X.; Yang, Z.; Zhang, H.; Liu, L.; Zhang, Y. Fast fabrication of a self-cleaning coating constructed with scallion-like $\mathrm{ZnO}$ using a perfect colloidal monolayer enabled by a predictive self-assembly method. J. Mater. Chem. A 2017, 5, doi:10.1039/c7ta00125h.

129. Ray, S.; Banerjee, R.; Basu, N.; Batabyal, A.K.; Barua, A.K. Properties of tin doped indium oxide thin films prepared by magnetron sputtering. J. Appl. Phys. 1983, 54, doi:10.1063/1.332415.

130. Prabhu, S.; Cindrella, L.; Joong Kwon, O.; Mohanraju, K. Superhydrophilic and self-cleaning rGO-TiO2 composite coatings for indoor and outdoor photovoltaic applications. Sol. Energy Mater. Sol. Cells 2017, 169, doi:10.1016/j.solmat.2017.05.023.

131. Di Filippo, M.; Bracken, C.; Baumann, M. Continuous flow photochemistry for the preparation of bioactive molecules. Molecules 2020, 25.

132. Du, Y.; Luna, L.E.; Tan, W.S.; Rubner, M.F.; Cohen, R.E. Hollow silica nanoparticles in UV - Visible antireflection coatings for poly(methyl methacrylate) substrates. ACS Nano 2010, 4, doi:10.1021/nn101033y.

133. Dudem, B.; Bharat, L.K.; Leem, J.W.; Kim, D.H.; Yu, J.S. Hierarchical Ag/TiO2/Si Forest-Like Nano/Micro-Architectures as Antireflective, Plasmonic Photocatalytic, and Self-Cleaning Coatings. ACS Sustain. Chem. Eng. 2018, 6, doi:10.1021/acssuschemeng.7b02220.

134. Han, K.S.; Shin, J.H.; Lee, H. Enhanced transmittance of glass plates for solar cells using nano-imprint lithography. Sol. Energy Mater. Sol. Cells 2010, 94, doi:10.1016/j.solmat.2009.12.001.

135. Son, J.; Kundu, S.; Verma, L.K.; Sakhuja, M.; Danner, A.J.; Bhatia, C.S.; Yang, H. A practical superhydrophilic self cleaning and antireflective surface for outdoor photovoltaic applications. Sol. Energy Mater. Sol. Cells 2012, 98, doi:10.1016/j.solmat.2011.10.011.

136. Liang, Z.; Zhou, Z.; Zhao, L.; Dong, B.; Wang, S. Fabrication of transparent, durable and self-cleaning superhydrophobic coatings for solar cells. New J. Chem. 2020, 44, doi:10.1039/d0nj01402h.

137. Pendse, S.; Chandra Sekhar Reddy, K.; Narendra, C.; Murugan, K.; Sakthivel, S. Dual-functional broadband antireflective and hydrophobic films for solar and optical applications. Sol. Energy 2018, 163, doi:10.1016/j.solener.2018.02.019.

138. Iyengar, V. V.; Nayak, B.K.; Gupta, M.C. Optical properties of silicon light trapping structures for photovoltaics. Sol. Energy Mater. Sol. Cells 2010, 94, doi:10.1016/j.solmat.2010.07.020.

139. Xing, M.; Wei, Y.; Wang, R.; Zhang, Z. Study on the performance of ZMO/PbS quantum dot heterojunction solar cells. Sol. Energy 2021, 213, doi:10.1016/j.solener.2020.11.023. 